\title{
Reduced Glutathione Level Promotes Epithelial-Mesenchymal Transition in Lens Epithelial Cells via a Wnt/ $\beta$-Catenin-Mediated Pathway
}

\section{Relevance for Cataract Therapy}

\author{
Zongbo Wei, ${ }^{\star}$ Jane Caty, ${ }^{\dagger}$ Jeremy Whitson, ${ }^{*}$ Amy D. Zhang, ${ }^{\dagger}$ Ramkumar Srinivasagan, ${ }^{*}$ Terrance J. Kavanagh, \\ Hong Yan, ${ }^{\S \pi}$ and Xingjun Fan*
}

\begin{abstract}
From the Department of Pathology, * Case Western Reserve University, Cleveland, Ohio; the Department of Ophthalmology, ${ }^{\dagger}$ University Hospitals of $^{-}$ Cleveland Medical Center, Cleveland, Ohio; the Department of Environmental and Occupational Health Sciences, ${ }^{\ddagger}$ University of Washington, Seattle, Washington; the Department of Ophthalmology, ${ }^{\S}$ Tangdu Hospital, The Fourth Military Medical University, Xi'an, China; and the Chongqing Key Laboratory of Ophthalmology and Chongqing Eye Institute," First Affiliated Hospital of Chongqing Medical University, Chongqing, China
\end{abstract}

\author{
Accepted for publication \\ July 26, 2017. \\ Address correspondence to \\ Xingjun Fan, Ph.D., Depart- \\ ment of Pathology, Case West- \\ ern Reserve University, 2103 \\ Cornell Rd, Wolstein Room \\ 5144, Cleveland, $\mathrm{OH}$ \\ 44106. E-mail: xxf3@case. \\ edu.
}

\begin{abstract}
The epithelial-mesenchymal transition (EMT) process plays a pivotal role in the pathogenesis of posterior capsular opacification because of remnant lens epithelial cell proliferation, migration, and transformation after cataract surgery. The latter, we hypothesize, may result in posterior capsule wrinkling and opacification because of a profound change in the lens growth environment via a 1000fold reduction of extracellular glutathione (GSH) levels. To test this hypothesis, we investigated the EMT process in cell culture and GSH biosynthesis deficiency mouse models. Our data indicate a dramatic increase of pro-EMT markers, such as type I collagen, $\alpha$-smooth muscle actin, vimentin, and fibronectin, under conditions of lens GSH depletion. Further study suggests that decreased GSH triggers the Wnt/ $\beta$ catenin signal transduction pathway, independent of transforming growth factor- $\beta$. Equally important, the antioxidants $\mathrm{N}$-acetyl cysteine and GSH ethyl ester could significantly attenuate the EMT signaling stimulated by decreased GSH levels. These findings were further confirmed by mock cataract surgery in both gamma glutamyl-cysteine ligase, catalytic subunit, and gamma glutamyl-cysteine ligase, modifier subunit, knockout mouse models. Remarkably, increased EMT marker expression, $\beta$-catenin activation, and translocation into the nucleus were found in both knockout mice compared with the wild type, and such increased expression could be significantly attenuated by $\mathrm{N}$-acetyl cysteine or GSH ethyl ester treatment. This study, for the first time we believe, links oxidative stress to lens fibrosis and posterior capsular opacification formation via EMT-mediated mechanisms. (Am J Pathol 2017, 187: 2399-2412; http://dx.doi.org/10.1016/j.ajpath.2017.07.018)
\end{abstract}

Cataract surgery remains the only effective procedure to treat cataracts, at an estimated worldwide rate of 30 million procedures each year. ${ }^{1}$ Even though cataract surgery is considered a highly safe and effective medical procedure, it often carries complications. Posterior capsule opacification (PCO) is the most common complication postoperatively. Proliferation, migration, and transdifferentiation of residual lens epithelial cells after surgery will subsequently cause
PCO and wrinkling that affects visual acuity, a condition also known as secondary cataract. ${ }^{2}$

PCO formation is considered to originate via a fibrotic process involving wound-healing and tissue-remodeling

Supported by NIH grants EY024553 (X.F.) and NEI P30EY-11373 (Case Western Reserve University Visual Science Research Center).

Disclosures: None declared. 
pathways initiated by traumatic injury during the surgical procedure. Growing evidence indicates that epithelialmesenchymal transition (EMT) of lens epithelial cells plays a key pathogenic role in PCO formation, ${ }^{3-5}$ which has also been well documented in organ fibrotic diseases, such as kidney, ${ }^{6,7}$ lung, and liver fibrosis. ${ }^{8,9}$ During EMT, lens epithelial cells lose their tight junction molecules and transdifferentiate into mesenchymal cells, a cell type with myofibroblast morphology that is more invasive and no longer maintains monolayer characteristics. Furthermore, promesenchymal cytoskeletal protein overproduction, such as $\alpha$ smooth muscle actin ( $\alpha$-SMA), also contributes to posterior capsule wrinkling. ${ }^{10,11}$ EMT is thought to be triggered by inflammatory cytokines and basement membrane proteolysis via metalloproteinases. ${ }^{12}$ Extensive studies from cell and ex vivo capsular bag culture models suggest that transforming growth factor (TGF)- $\beta$ is a critical regulator of lens EMT pathogenesis, which is mediated by Smad-dependent ${ }^{13,14}$ and Smad-independent ${ }^{3,15}$ signaling cascade. This results in upregulation of various profibrotic genes, including fibronectin, type I and III collagen, ${ }^{16-18} \alpha$-SMA, vimentin and desmin, ${ }^{10,19}$ matrix metalloproteinases 2 and $9,{ }^{20}$ and integrins, such as $\alpha 5, \alpha 11$, and $\alpha \mathrm{V} \beta 5$. $^{21}$

Moderate chronic oxidative stress has been suggested to play a pivotal role in organ fibrosis and tumor metastasis. ${ }^{22}$ Reactive oxygen species (ROS) and oxidative stress have also been implicated in modulating EMT signaling. ${ }^{23}$ Mori et $\mathrm{al}^{24}$ found that the mouse mammary gland epithelial cell line NMuMG could convert to a fibroblast-like cell type after several days of challenge by a low dosage of hydrogen peroxide. This transformation was accompanied by an upregulation of integrins $(\alpha 2, \alpha 6$, and $\beta 3)$ and several matrix metalloproteinases and an E-cadherin redistribution via a mitogen-activated protein kinase signaling cascade. A similar study $^{25}$ was reported in HK-2 normal kidney epithelial cell malignant transformation under a noncytotoxic dose of hydrogen peroxide that resulted in significant up-regulation of mesenchymal markers, such as $\beta$-catenin, vimentin, and $\alpha$-SMA. The reciprocal interplay between ROS and the most potent profibrogenic cytokine, TGF- $\beta$, critically modulates cell proliferation, extracellular matrix deposition, and cell transdifferentiation. ${ }^{26-29}$ This is well supported by observations of NADPH oxidase, an ROS production enzyme, that is up-regulated in various fibrotic diseases. ${ }^{30-32}$ Furthermore, significant declines in glutathione (GSH) levels have been documented in experimental fibrosis models ${ }^{33,34}$ and in various human fibrotic diseases, including cystic fibrosis, ${ }^{35}$ pulmonary fibrotic disease, ${ }^{36}$ and liver fibrosis. ${ }^{37}$ However, the pathogenic role of ROS and oxidative stress in lens epithelial cell fibrosis, as well as in PCO formation after cataract surgery, remains unknown.

In the present study, we used cell culture, chronic oxidative stress mouse models, and mouse mock cataract surgery models to address the role of chronic oxidation in the pathogenesis of lens epithelial cell fibrosis via EMT and its signaling pathways.

\section{Materials and Methods}

\section{Reproducibility}

All experiments shown in figures, unless mentioned specifically, consist of at least five biological replicates that are reproducible.

\section{Reagents}

All chemicals used were of analytical reagent grade. Milli-Q water (Millipore, Billerica, MA) was used for preparation of standards and reagents. Human TGF- $\beta 2, \mathrm{~N}$-acetyl cysteine (NAC), GSH, GSH ethyl ester (GSH-EE), XAV939, buthionine sulfoximine (BSO), dimethyl fumarate (DMF), and all other sodium salt and chemical reagents were purchased from Sigma-Aldrich (St. Louis, MO).

\section{Animals}

All animal experiments were conducted in accordance with procedures approved by the Case Western Reserve University (Cleveland, OH) Animal Care and Use Committee and conformed to the Association for Research in Vision and Ophthalmology Statement for Use of Animals in Ophthalmic and Vision Research. Animals were housed under a diurnal lighting condition and allowed free access to food and water. The lens conditional gamma glutamylcysteine ligase, catalytic subunit $(G c l c)$, knockout (KO) mice, named LEGSKO mice, were generated by our group, as has been described in our previous report. ${ }^{38}$ The systemic gamma glutamyl-cysteine ligase, modifier subunit $(\mathrm{Gclm})$, KO mice ${ }^{39}$ were kindly provided by Terrence J. Kavanagh (University of Washington, Seattle, WA).

\section{Cell Culture}

Human lens epithelial (HLE-B3) cells were grown in Dulbecco's modified Eagle's medium with $10 \%$ fetal bovine serum, $2 \mathrm{mmol} / \mathrm{L}$ glutamine, and $50 \mathrm{U} / \mathrm{mL}$ penicillin/streptomycin (ThermoFisher, Waltham, MA) at $37^{\circ} \mathrm{C}$ in a humidified $5 \% \mathrm{CO}_{2}$ incubator. For primary porcine lens epithelial cell culture, pig eyes were collected at a local slaughterhouse within 2 hours of postmortem time, placed on ice, and transported to the laboratory (approximately 1 hour) for immediate processing. First, the isolated lens was incubated with $2 \mathrm{~mL}$ of $0.25 \%$ trypsin at $37^{\circ} \mathrm{C}$ for 2 minutes to remove any attached nonlens cells. Then, after a brief rinse with Hanks' balanced salt solution (HBSS), the lens capsule was isolated and rinsed three times with HBSS before incubation with $2 \mathrm{~mL}$ of $0.5 \%$ trypsin for 5 minutes. Complete Dulbecco's modified Eagle's medium $(5 \mathrm{~mL})$ was added, and tissue was disrupted by pipetting up and down 10 to 15 times with a pipette fitted with a $1000-\mu \mathrm{L}$ tip. The tissue homogenate was then passed through a $100-\mu \mathrm{m}$ cell strainer. The cells were collected by low-speed 
centrifugation at $150 \times g$ and placed in a $35-\mathrm{mm}$ laminincoated tissue culture dish with Dulbecco's modified Eagle's medium supplied with $10 \%$ fetal bovine serum, $2 \mathrm{mmol} / \mathrm{L}$ glutamine, and $50 \mathrm{U} / \mathrm{mL}$ penicillin/streptomycin (ThermoFisher). Cells were cultured at $37^{\circ} \mathrm{C}$ in a humidified incubator with $5 \% \mathrm{CO}_{2}$.

\section{Mouse Lens ex Vivo Culture}

The isolated intact lens was rinsed three times with HBSS and then cultured in 12-well plates with serum-free Medium 199 with antibiotics penicillin and streptomycin (ThermoFisher) at $37^{\circ} \mathrm{C}$ in a $5 \% \mathrm{CO}_{2}$ incubator.

\section{Treatment Procedures}

Cells were seeded 24 hours before the treatment. Indicated concentrations of BSO, DMF, NAC, GSH-EE, or TGF- $\beta 2$ were added to a fresh serum-free Dulbecco's modified Eagle's medium and incubated at various intervals, as indicated. After treatment, cells were harvested after three washes with ice-cold phosphate-buffered saline and subjected to immunoblot or other assays, as described below. For whole lens culture, the serum-free medium, with or without BSO, NAC, GSH-EE, or TGF- $\beta 2$, was incubated immediately after isolation for 48 hours; the lens capsule was collected for further analysis.

\section{Mouse Mock Cataract Surgery}

Age-matched 4-month-old mice were used in this study. Mice were anesthetized by a ketamine-xylazine cocktail, and a central corneal incision was made. The lens fiber mass was gently removed by hydrodissection using a 3-mL HBSS syringe fitted with a 30-gauge flat-tipped cannula. The remaining lens capsule was carefully washed and filled by HBSS to remove any lens fiber debris and to restore ocular chamber morphology, followed by a single 10-0 nylon suture to close the incision. The careful central corneal incision does not affect ocular vascular tissues; typically, there is no visible blood present in the entire procedure. In addition, no clearly noticeable discomfort/pain was observed in these mice postoperatively. Eye drops containing the antibiotic ofloxacin were applied once immediately after surgery, and mice were sacrificed at 2, 3, 4, and 5 days after surgery. For each mouse, bilateral surgical procedures were performed, and $25 \mu \mathrm{L}$ of $10 \mathrm{mmol} / \mathrm{L} \mathrm{NAC}$ or $2 \mathrm{mmol} / \mathrm{L}$ of GSH-EE in HBSS was injected into the right eye chamber immediately after surgery. Continual eye drop topical application was given every 6 hours from 7 AM to $11 \mathrm{PM}$. The untreated left eye served as a control. Eyes collected immediately after surgery served as a time 0 control. At least six mice were used in each group. At each time point, mice were euthanized, and eyes were carefully dissected, placed in 4\% paraformaldehyde for 18 hours, and then subjected to paraffin embedding and sectioning.

\section{Immunofluorescence}

For paraffin-embedded slides, sections $(6 \mu \mathrm{m}$ thick $)$ were deparaffinized and rehydrated using a standard procedure. The slide was washed by phosphate-buffered saline for 10 minutes, and antigen retrieval was performed in $0.1 \mathrm{~mol} / \mathrm{L}$ sodium citrate buffer, $\mathrm{pH} 6.0$, in a microwave oven using a 4 minutes at power 5 plus 8 minutes at power 3 program. The slide was then blocked and permeabilized by $5 \%$ normal goat serum and $0.3 \%$ Triton X-100 for 30 minutes. The primary antibodies, the rabbit polyclonal collagen I antibody (1:250; Abcam, Cambridge, MA), the rabbit polyclonal vimentin (1:500; ThermoFisher), the mouse monoclonal fibronectin antibody (1:5; Developmental Studies Hybridoma Bank, University of Iowa, Iowa City, IA), the mouse monoclonal active $\beta$-catenin (Tyr489; 1:10; Developmental Studies Hybridoma Bank), and/or the fluorescein isothiocyanate-labeled mouse monoclonal $\alpha$-SMA antibody (1:1000; Sigma-Aldrich), were applied in $0.1 \%$ bovine serum albumin phosphate-buffered saline solution and incubated at $4{ }^{\circ} \mathrm{C}$ overnight in a humid chamber. After wash, the Alexa-488 or/and the Alexa-594 conjugated secondary antibodies (ThermoFisher) were then applied and incubated at room temperature for 1 hour in a humid chamber. After wash, the slide was mounted with the Prolong antifade with DAPI (ThermoFisher). For lens explant culture, the explant was briefly fixed with $10 \%$ formaldehyde for 10 minutes and then subjected to a direct staining procedure without an antigen retrieval step.

\section{Confocal Microscope}

All confocal images were collected by a Leica SP8 gated stimulated emission depletion confocal microscope (Leica, Wetzlar, Germany) equipped with two hybrid, spectral module for gapless multi-spectral imaging detectors; the Acoudto-Optical Beam Splitter system lasers include a 405nm laser, argon (458, 476, 488, 496, or $514 \mathrm{~nm})$, a tunable white light $(470$ to $670 \mathrm{~nm}$ ), and a 592-nm stimulated emission depletion laser. For proper comparison, each channel of fluorescence was adjusted to the highest sensitivity/intensity but without oversaturation from samples with the strongest signal. In this case, Gclc and Gclm KO mice samples were used for such purpose. The parameters were then used for all sample image collection. At least 10 images were captured from each sample.

\section{GSH Assay}

Intracellular GSH was determined by liquid chromatography/mass spectrometry, as described in our previous study. ${ }^{40}$ In brief, cells were washed three times with ice-cold $\mathrm{Ca}^{2+} / \mathrm{Mg}^{2+}$-free phosphate-buffered saline, harvested via the cell scraper, and transferred to a prechilled $1.5-\mathrm{mL}$ pestle tube (Kimble, Rockwood, TN) with $250 \mu \mathrm{L}$ ice-cold extraction buffer, $0.1 \%$ Triton X-100, and $0.6 \%$ sulfosalicylic acid. Cells were homogenized by a pestle for 1 minute 
A
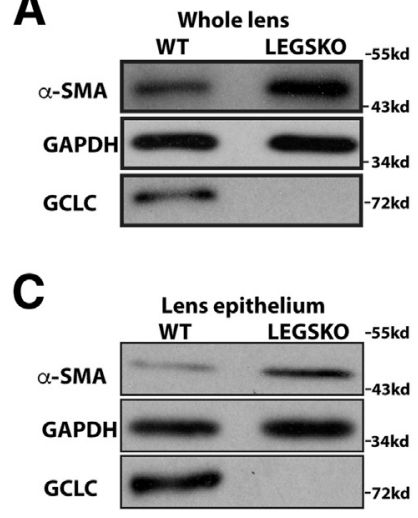

E

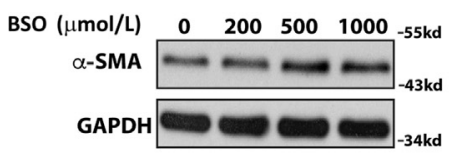

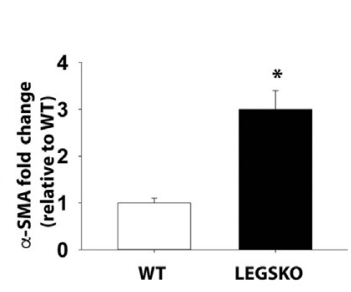

B
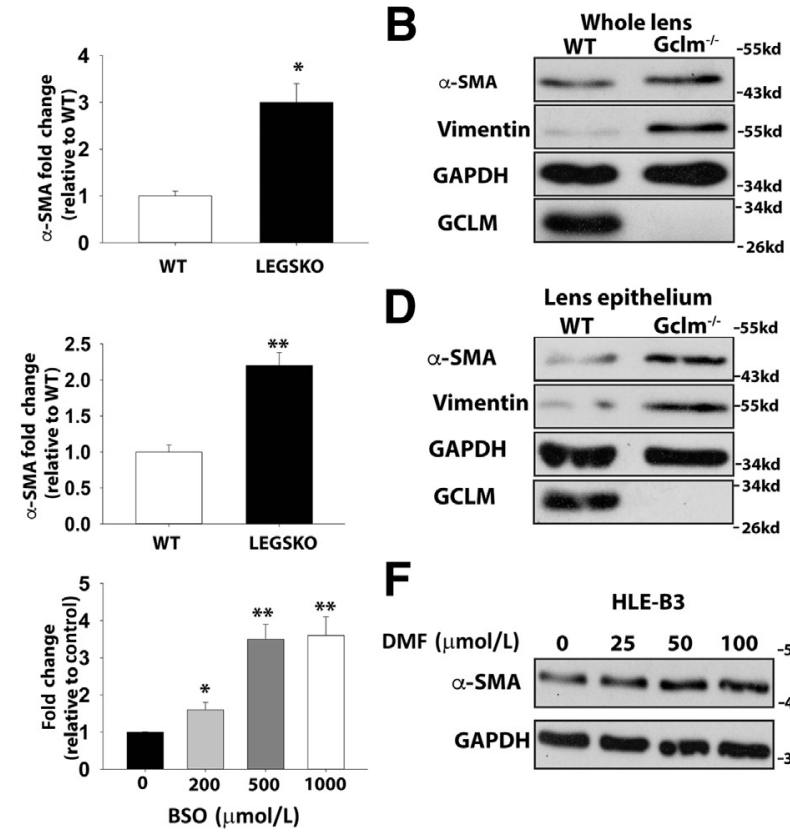

D
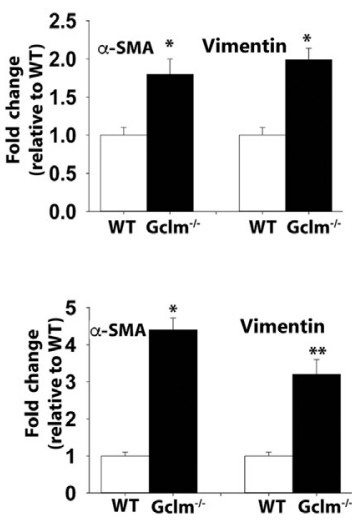

$\mathbf{F}$
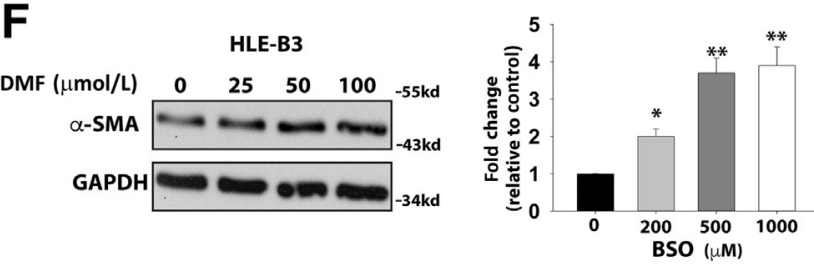

Figure 1 Epithelial-mesenchymal transition (EMT) markers are enhanced in LEGSKO and GCLM knockout (KO) mice at 4 months. Lens or cell homogenate was analyzed by immunoblot probing $\alpha$-smooth muscle actin ( $\alpha$-SMA), vimentin, GCLC, GCLM, and glyceraldehyde-3-phosphate dehydrogenase (GAPDH). A: $\alpha$ SMA is increased in the whole lens homogenate of LEGSKO mice compared with WT. B: $\alpha$-SMA and vimentin are increased in the whole lens homogenate of Gclm KO mice compared with WT. C: $\alpha$-SMA is increased in LEGSKO lens epithelium compared with wild-type (WT). D: $\alpha$-SMA and vimentin levels are increased in Gclm KO mice lens epithelium compared with WT. E: $\alpha$-SMA expression is increased in human lens epithelial (HLE-B3) cells after treatment with an increased concentration of buthionine sulfoximine (BSO) for 24 hours F: $\alpha$-SMA expression is increased in HLE-B3 cells after treatment with an increasing concentration of dimethyl fumarate (DMF) for 24 hours. GAPDH was used as a loading control. GCLC and GCLM blotting served as additional genotype verification besides PCR genotype conclusion. A $t$-test was used to compare WT and K0 groups, and $P<0.05$ is considered significant. Data are expressed as means $\pm \mathrm{SEM}$ (A-F). $n=6$ (whole lens); $n=3$ (epithelium). ${ }^{*} P<0.05,{ }^{*} P<0.01$ versus WT or control.

and then sonicated for 2 minutes under an ice-water bath. The supernatant, after 10 minutes of centrifugation at $25,000 \times g$, was collected; formic acid was added to a final concentration of $0.1 \%$ and then subjected to liquid chromatography/mass spectrometry analysis. The GSH was calculated as $\mathrm{nmol} / \mathrm{mg}$ protein.

\section{Immunoblot Assay}

Cells, whole lenses, and lens capsules were collected and lysed in lysis buffer containing $20 \mathrm{mmol} / \mathrm{L}$ Tris, $\mathrm{pH} \mathrm{7.5,} 1$ $\mathrm{mmol} / \mathrm{L}$ EDTA, $1 \mathrm{mmol} / \mathrm{L}$ EGTA, $150 \mathrm{mmol} / \mathrm{L} \mathrm{NaCl}, 1 \%$ Triton X-100, $2.5 \mathrm{mmol} / \mathrm{L}$ sodium pyrophosphate, $1 \mathrm{mmol} / \mathrm{L}$ $\alpha$-glycerolphosphate, $1 \mathrm{mmol} / \mathrm{L} \mathrm{Na}_{3} \mathrm{VO}_{4}, 1 \mathrm{mg} / \mathrm{mL}$ leupeptin, and $1 \mathrm{mmol} / \mathrm{L}$ phenylmethylsulfonyl fluoride on ice for 10 minutes. The protein concentration from the supernatant was determined by protein bicinchoninic acid assay (ThermoFisher). The protein extract was further processed for immunoblot analysis and probed for $\alpha$-SMA, collagen I, vimentin, phosphorylated Smad2, phosphorylated Smad3, phosphorylated glycogen synthase kinase $3 \beta$ (GSK-3 $\beta$ ), and $\beta$-catenin. No glyceraldehyde-3-phosphate dehydrogenase expression changes relevant to total protein were found in our working models (Supplemental Figure S1) and, therefore, all data were normalized to the level of glyceraldehyde3-phosphate dehydrogenase.

\section{Statistical Analysis}

All values were expressed as means \pm SEM. Statistical analysis was performed according to methods previously described in detail. ${ }^{41}$ In brief, a $t$-test and a one-way analysis of variance test were computed using SPSS software version 24 (IBM, Armonk, NY). $P<0.05$ was considered significant.

\section{Results}

\section{EMT Marker Expression Is Enhanced in Lenses of LEGSKO and $\mathrm{GClm}^{-/-}$Mice}

Two genetically engineered mouse models targeting GSH $d e$ novo synthesis were tested. The lens conditional Gclc KO $\left(\mathrm{Gclc}^{-l-} ; \mathrm{LEGSKO}^{38}\right)$ mouse has more than $50 \%$ suppressed GSH levels (1.0 to $1.5 \mathrm{mmol} / \mathrm{L}$ ) compared with the wild type (WT; 3 to $5 \mathrm{mmol} / \mathrm{L}$ ). ${ }^{38}$ The somatic $\mathrm{Gclm} \mathrm{KO}$ mouse $\left(\mathrm{Gclm}^{-1-}\right)$ has $>70 \%$ suppression of lens GSH levels ( 0.8 to $1.2 \mathrm{mmol} / \mathrm{L}$ ) versus the WT lens. ${ }^{40}$ All mice in this study were in a C57BL/6 genetic background and age matched at 4 months. Whole lens and lens epithelium (lens capsule with adherent lens epithelia) were used to test various mesenchymal-like marker expression. A more than threefold and twofold increase of $\alpha$-SMA expression was seen by 
A

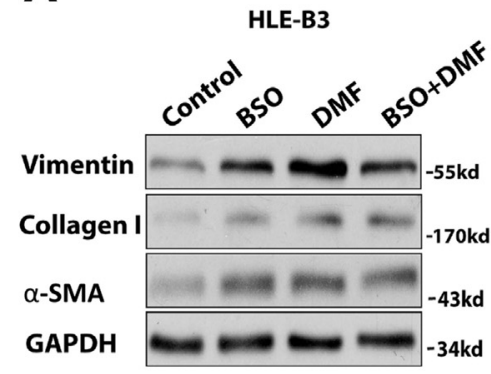

C

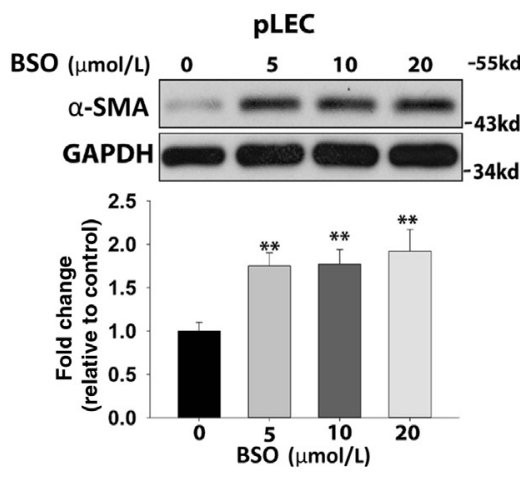

B
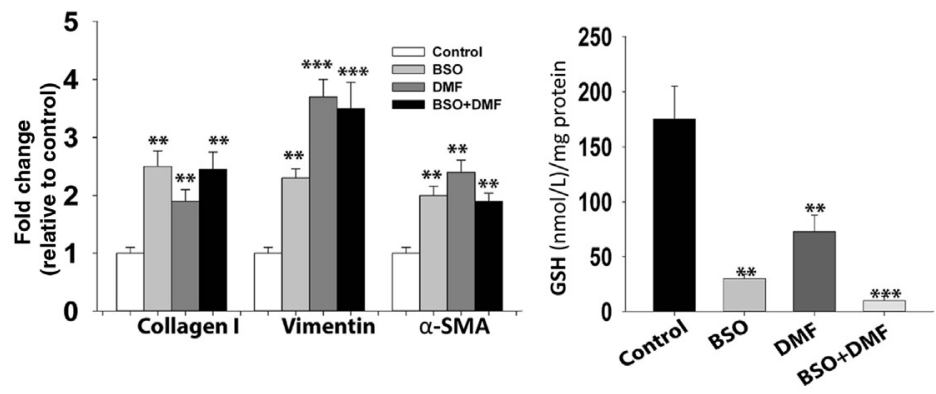

E

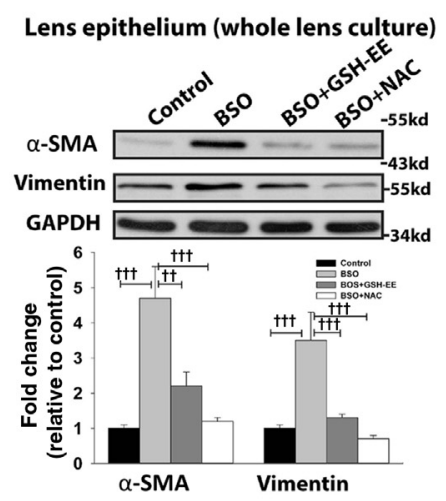

Figure 2 EMT markers are elevated under GSH depletion condition. A: Significantly increased expression of collagen I, vimentin, and $\alpha$-smooth muscle actin $(\alpha-S M A)$ is seen in $500 \mu \mathrm{mol} / \mathrm{L}$ buthionine sulfoximine (BSO), $25 \mu \mathrm{mol} / \mathrm{L}$ dimethyl fumarate (DMF), and $500 \mu \mathrm{mol} / \mathrm{L}$ BSO plus $25 \mu \mathrm{mol} / \mathrm{L}$ DMF stimulated cells for 24 hours. B: The intracellular GSH concentration after 24 hours of treatment with $500 \mu \mathrm{mol} / \mathrm{L} \mathrm{BS0}, 25 \mu \mathrm{mol} / \mathrm{L} \mathrm{DMF}$, or $500 \mu \mathrm{mol} / \mathrm{L}$ BSO combined with $25 \mu \mathrm{mol} / \mathrm{L}$ DMF. C: $\alpha$-SMA expression increases in porcine lens epithelial cells (pLECS) after treatment with an increased concentration of BSO for 24 hours D: $\alpha$-SMA production is alleviated in human lens epithelial (HLE-B3) cells when cotreated with either $10 \mathrm{mmol} / \mathrm{L} \mathrm{N}$-acetyl cysteine (NAC) or $0.5 \mathrm{~mol} / \mathrm{L} \mathrm{GSH}$ ethyl ester (GSH$\mathrm{EE})$ with $500 \mu \mathrm{mol} / \mathrm{L}$ BSO for 24 hours. E: $\alpha$-SMA and vimentin production are alleviated in the lens epithelium from cultured whole lens when cotreated with 10 $\mathrm{mmol} / \mathrm{L} \mathrm{NAC}$ or $0.5 \mathrm{mmol} / \mathrm{L} \mathrm{GSH}$-EE with $500 \mu \mathrm{mol} / \mathrm{L}$ BSO for 48 hours. Glyceraldehyde-3-phosphate dehydrogenase (GAPDH) was used as a loading control. Oneway analysis of variance and $t$-test were used to compare WT and knockout groups, and $P<0.05$ is considered significant. $n=5$ for each immunoblot. ${ }^{*} P<0.05$, $* * P<0.01$, and ${ }^{* * *} P<0.001$ versus control; ${ }^{\dagger} P<0.05,{ }^{\dagger \dagger} P<0.01$, and ${ }^{\dagger \dagger \dagger} P<0.001$.

immunoblot in the whole lens protein extract of $\mathrm{Gclc}^{-1-}$ and $\mathrm{Gclm}^{-1-}$ compared with WT, respectively (Figure 1, A and B). More than twofold and fourfold increases of lens epithelium $\alpha$-SMA expression was seen in $\mathrm{Gclc}^{-1-}$ and $\mathrm{Gclm}^{-1-}$ mice compared with WT, respectively (Figure 1, C and D). Similarly, significantly increased vimentin was also found in both whole lens and lens epithelium of the $\mathrm{Gclm}^{-/-}$ mice compared with WT (Figure 1, B and D).

\section{Blocking Intracellular GSH Biosynthesis Prompts EMT in Human and Porcine Lens Epithelial Cells}

To test whether the above findings from mouse experimental models also occur in cell culture systems, we treated the HLE-B3 and primary cultured porcine lens epithelial cells with or without BSO or DMF to deplete GSH. $\alpha$-SMA expression was significantly up-regulated after 24 hours of treatment with an increasing concentration of BSO and DMF (Figure 1, E and F). Some degree of dose-response, up to $500 \mu \mathrm{mol} / \mathrm{L}$ BSO and $50 \mu \mathrm{mol} / \mathrm{L}$ DMF, was noted. However, further increasing BSO or DMF had only moderate effects on $\alpha$-SMA expression. We used $500 \mu \mathrm{mol} / \mathrm{L}$ BSO and $25 \mu \mathrm{mol} / \mathrm{L}$ DMF conditions for the rest of our HLE-B3 studies, and the intracellular GSH concentration with or without treatment is shown in Figure 2B. Type I collagen and vimentin were significantly elevated in HLEB3 cells after a 24-hour challenge with BSO, DMF, or BSO combined with DMF (Figure 2A). Interestingly, a 100 times lower concentration of BSO $(5 \mu \mathrm{mol} / \mathrm{L})$ stimulated a

Table 1 The Total and Active TGF- $\beta 2$ in Aqueous Humor

\begin{tabular}{lrrc}
\hline TGF- $\beta 2$ & \multicolumn{1}{l}{ WT } & \multicolumn{1}{l}{ LEGSK0 } & \multicolumn{1}{c}{$\mathrm{Gclm}^{-/-}$} \\
\hline Total, $\mathrm{pg} / \mathrm{mL}$ & $1012.3 \pm 47.8$ & $1007.9 \pm 72.8$ & $997.91 \pm 107.2$ \\
Active, $\mathrm{pg} / \mathrm{mL}$ & $5.21 \pm 2.43$ & $6.06 \pm 3.22$ & $4.17 \pm 2.71$ \\
\hline
\end{tabular}

Data are expressed as means \pm SEM.

TGF- $\beta 2$, transforming growth factor- $\beta 2$. 
A

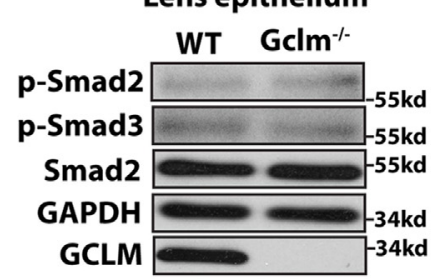

B

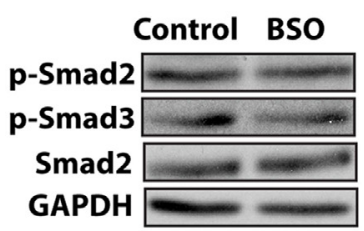

C

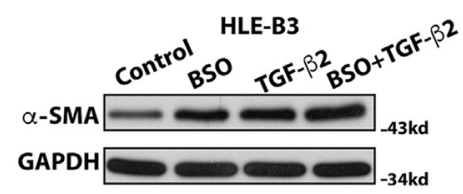

D

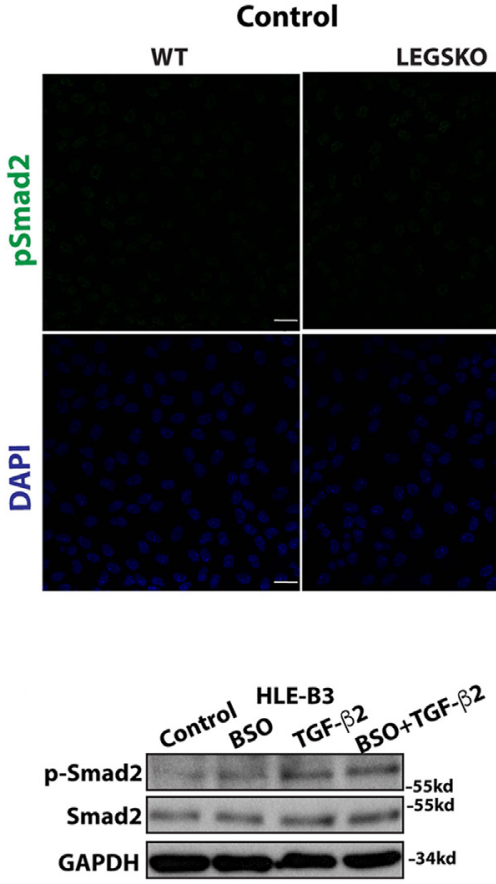

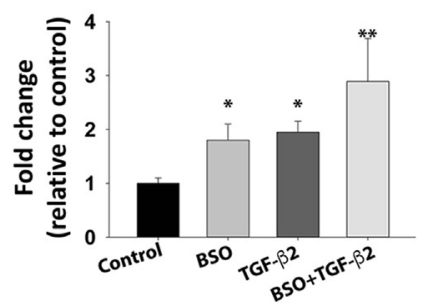
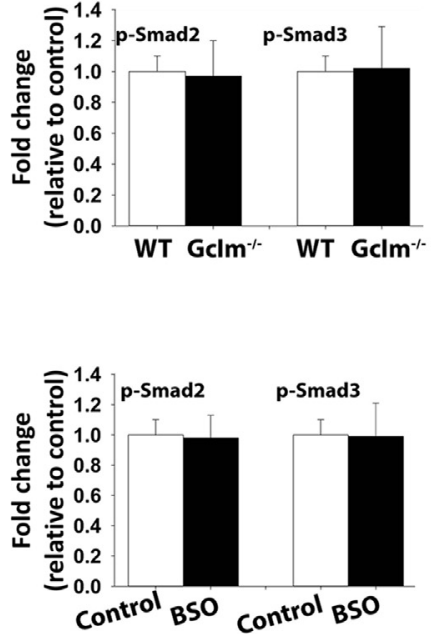

TGF- $\beta 2$

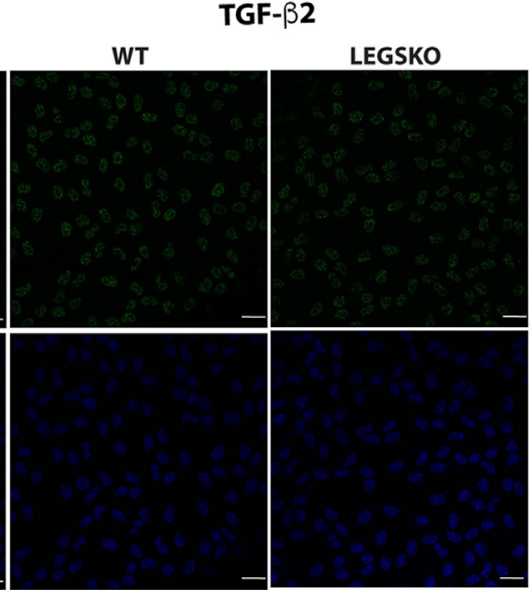

Figure 3 EMT signaling triggered by decreased GSH levels is independent of canonical transforming growth factor (TGF)- $\beta$ signaling. A: No remarkable changes of phosphorylated Smad2 and Smad3 ( $\mathrm{p}$-Smad2 and p-Smad3, respectively) are seen in lens epithelium from $\mathrm{Gclm}$ knockout (KO) mice compared with WT. B: No remarkable changes of $\mathrm{p}$-Smad2 and $\mathrm{p}$-Smad3 are seen in human lens epithelial (HLE-B3) cells challenged by $500 \mu \mathrm{mol} / \mathrm{L}$ buthionine sulfoximine (BSO) for 24 hours. C: Synergistic effect is seen in HLE-B3 cells challenged by $500 \mu \mathrm{mol} / \mathrm{L} \mathrm{BS0}, 1 \mathrm{ng} / \mathrm{mL}$ TGF- $\beta 2$, and $500 \mu \mathrm{mol} / \mathrm{L}$ BSO plus $1 \mathrm{ng} / \mathrm{mL}$ TGF- $\beta 2$ for 24 hours. D: TGF- $\beta 2$ stimulation increased Smad2 phosphorylation, but no remarkable change was seen between LEGSKO and WT mice. E: TGF- $\beta 2$ stimulation increased Smad2 phosphorylation, but no remarkable change was seen between HLE-B3 cells treated with or without BSO. Glyceraldehyde-3phosphate dehydrogenase (GAPDH) was used as a loading control. One-way analysis of variance and $t$-test were used to compare WT and KO groups, and $P<0.05$ is considered significant. $n=5$ for each immunoblot. ${ }^{*} P<0.05,{ }^{*} P<0.01$, and ${ }^{* * *} P<0.001$ versus control; ${ }^{\dagger \dagger \dagger} P<0.001$. Scale bars $=25 \mu \mathrm{m} . \alpha$-SMA, $\alpha$-smooth muscle actin. similar fold of $\alpha$-SMA production in primary porcine lens epithelial cells in 24 hours (Figure 2C). Higher dosages of BSO $(>100 \mu \mathrm{mol} / \mathrm{L})$ were found to trigger massive cell death and detachment, indicating cell apoptosis rather than transformation consequences. These results indicate that moderate oxidative stress regulates intracellular gene expression and cell transformation, whereas an overdose of oxidative stress triggers cell death. 
A

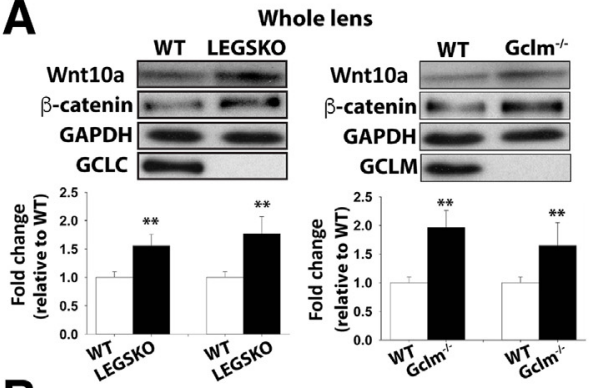

B
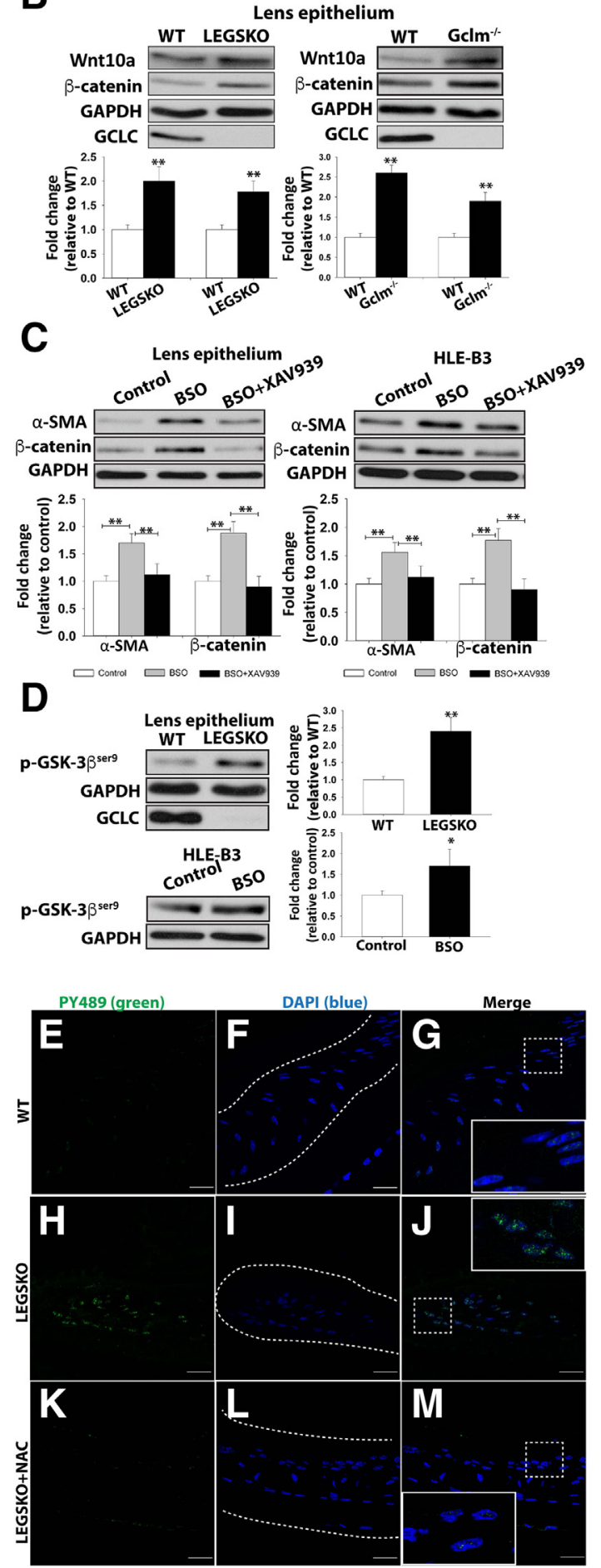

Inversely, we attempted to rescue cell transformation by antioxidant treatment. $\alpha$-SMA production in HLE-B3 cells was significantly attenuated when cells were cotreated with either $10 \mathrm{mmol} / \mathrm{L} \mathrm{NAC}$ or $0.5 \mathrm{mmol} / \mathrm{L}$ GSH-EE, two sulfhydryl-based antioxidants. In particular, $10 \mathrm{mmol} / \mathrm{L}$ NAC could completely abolish the BSO-induced $\alpha$-SMA production in HLE-B3 cell culture models, and GSH-EE could partially, but significantly, block $\alpha$-SMA production (Figure 2D). In addition, $\alpha$-SMA and vimentin production in the mouse lens ex vivo culture was also tested. A $>4.5$ fold increase of $\alpha$-SMA and an approximately 3.5 -fold increase of vimentin were seen in lenses treated with 500 $\mu \mathrm{mol} / \mathrm{L}$ BSO, a $\gamma$-glutamyl cysteine ligase inhibitor, for 48 hours compared with medium alone. Furthermore, the elevated $\alpha$-SMA and vimentin expression could be completely blocked by $10 \mathrm{mmol} / \mathrm{L} \mathrm{NAC}$ and partially attenuated by $0.5 \mathrm{mmol} / \mathrm{L}$ GSH-EE (Figure $2 \mathrm{E}$ ).

\section{Oxidative Stress via Declined GSH Level-Mediated EMT Is Modulated by a TGF- $\beta$-Independent Pathway}

Given the fact that TGF- $\beta$ is a potent profibogentic cytokine in EMT signaling, we wanted to clarify whether higher mesenchymal-like marker expression levels are the consequence of higher TGF- $\beta$ levels in $\mathrm{Gclc}^{-1-}$ or $\mathrm{Gclm}^{-1-}$ mouse, particularly in the aqueous humor, where the major isoform, TGF- $\beta 2$, directs lens epithelial cell signaling transduction, as has been reported in previous studies. ${ }^{42,43}$ Total and active TGF- $\beta 2$ in aqueous humor were determined by enzyme-linked immunosorbent assay. As shown

\footnotetext{
Figure 4 0xidative stress-modulated EMT signaling is mediated via the Wnt/ $\beta$-catenin signaling pathway. A: Wnt10a and $\beta$-catenin are elevated in the whole lens protein extract in both LEGSKO and Gclm knockout (KO) mice compared with WT. B: Similarly, Wnt10a and $\beta$-catenin are significantly $(P<0.01)$ elevated in the lens epithelium protein extract in both LEGSKO and Gclm KO mice compared with WT. C: The $\alpha$-smooth muscle actin ( $\alpha$-SMA) and $\beta$-catenin production is blocked when XAV939, a Wnt inhibitor, is coincubated with $500 \mu \mathrm{mol} / \mathrm{L}$ buthionine sulfoximine (BSO) in lens ex vivo culture (lens epithelium was extracted for immunoblot analysis) and human lens epithelial (HLE-B3) cells. D: The Ser9 phosphorylation of glycogen synthase kinase (GSK)-3 $\beta \quad\left(p-G S K-3 \beta^{\text {Ser9 }}\right.$ ) is significantly elevated in LEGSKO lens epithelium compared with WT and also in HLE-B3 cells after stimulation with $500 \mu \mathrm{mol} / \mathrm{L}$ BSO for 24 hours. GSH ethyl ester and $\mathrm{N}$-acetyl cysteine (NAC) attenuate $\beta$-catenin expression and GSK-3 $\beta^{\text {Ser9 }}$ phosphorylation, respectively. E-M: Immunofluorescence image of activated $\beta$-catenin colocalization within the nucleus. The active $\beta$-catenin, Tyr489 phosphorylated $\beta$-catenin, was labeled in green, and the lens epithelial cell nucleus was labeled in blue by DAPI. Boxed areas are shown at higher magnification in the insets. Dotted lines illustrate the boundary of the lens capsule. $\mathbf{E}-\mathbf{G}$ : WT lens capsule 72 hours after surgery demonstrates mild $\beta$-catenin nuclear translocation. $\mathbf{H}-\mathbf{J}$ : LEGSKO mice lens capsule demonstrates robust nucleus translocation of $\beta$ catenin. $\mathbf{K}-\mathbf{M}$ : The active $\beta$-catenin nuclear translocation was significantly attenuated when $10 \mathrm{mmol} / \mathrm{L} \mathrm{NAC}$ was applied immediately after surgery. For immunoblot, all data have been adjusted for glyceraldehyde-3phosphate dehydrogenase (GAPDH) level. One-way analysis of variance and $t$-test were used to compare WT and KO groups, and $P<0.05$ is considered significant. $n=5$ in each assay. ${ }^{*} P<0.05,{ }^{*} P<0.01$ versus WT or control. Scale bars $=25 \mu \mathrm{m}(\mathbf{E}-\mathbf{M})$.
} 


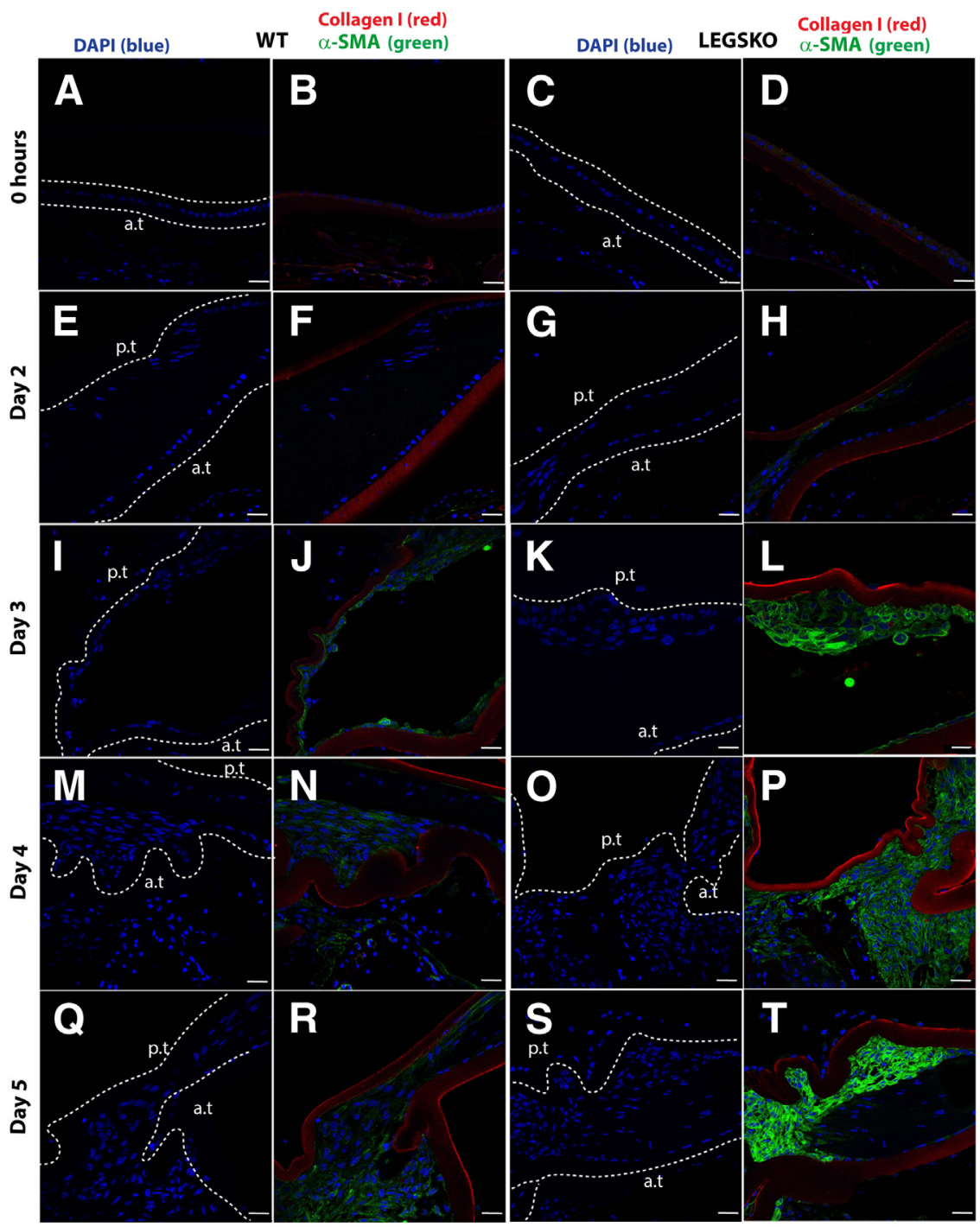

Figure 5 LEGSKO mouse promotes type I collagen and $\alpha$-smooth muscle actin ( $\alpha$-SMA) production in the mock cataract surgery in vivo model. Type I collagen (red fluorescence) and $\alpha$ SMA (green) are costained in mouse lens capsule 2 to 5 days after mock cataract surgery by removing lens fiber mass. The lens nucleus was stained with DAPI (blue). Dotted lines illustrate the boundary of the lens capsule. A, E, I, M, $\mathbf{Q}$ and $\mathbf{C}, \mathbf{G}, \mathbf{K}, \mathbf{0}, \mathbf{S}$ : Nucleus DAPI stain. $\mathbf{B}, \mathbf{F}, \mathbf{J}, \mathbf{N}, \mathbf{R}$ and $\mathbf{D}, \mathbf{H}, \mathbf{L}, \mathbf{P}, \mathbf{T}$ : Merged images colocalized for collagen I (red), $\alpha$ SMA (green), and nucleus (blue). A and B: WT lens capsule at time 0 . $\mathbf{C}$ and $\mathbf{D}$ : LEGSKO lens capsule at time $\mathbf{0}$. $\mathbf{E}$ and $\mathbf{F}$ : WT lens capsule at post-surgery day 2. G and H: LEGSKO lens capsule at postsurgery day 2. I and J: WT lens capsule at postsurgery day $3 . \mathbf{K}$ and L: LEGSKO lens capsule at post-surgery day 3. $\mathbf{M}$ and $\mathbf{N}$ : WT lens capsule at post-surgery day 4. $\mathbf{0}$ and P: LEGSKO lens capsule at post-surgery day 4. $\mathbf{Q}$ and R: WT lens capsule at post-surgery day 5 . $\mathbf{S}$ and T: LEGSKO lens capsule at post-surgery day 5 . Six mice at each time point were used. The same confocal parameters in each channel were used to capture the image from all of the samples. Scale bars $=25 \mu \mathrm{m}(\mathbf{A}-\mathbf{T})$. a.t., anterior capsule; p.t., posterior capsule.

in Table 1, there were no noticeable concentration changes in the total or active form of TGF- $\beta 2$ in the aqueous humor between LEGSKO or $\mathrm{Gclm}^{-1-}$ mice and WT. In addition, the phosphorylation status of Smad2 and Smad3, a key event in the canonical TGF- $\beta$ pathway, showed no remarkable changes in the lens epithelium of $\mathrm{Gclm}^{-/-}$mice compared with WT, or in HLE-B3 cells with or without BSO stimulation (Figure 3, A and B). To further test the effects of decreased GSH levels on TGF- $\beta$ signaling, we investigated the Smad2 phosphorylation status under $1 \mathrm{ng} / \mathrm{mL}$ TGF- $\beta 2$ stimulation in both WT and LEGSKO mice lens explants and HLE-B3 cells with or without BSO treatment. A significant elevation of Smad2 phosphorylation after TGF- $\beta 2$ stimulation in both culture systems was seen, but no remarkable changes were seen between LEGSKO and WT mice or in HLE-B3 cells with or without BSO treatment (Figure 3, D and E). These results indicate that up-regulation of mesenchymal-like markers in lens epithelial cells via decreased GSH content is independent of TGF- $\beta 2$. To further define the relationship between ROS and TGF- $\beta$ in EMT signaling, we tested the expression of the EMT marker $\alpha$-SMA in HLE-B3 cells after treatment with $500 \mu \mathrm{mol} / \mathrm{L}$ BSO, $1 \mathrm{ng} / \mathrm{mL}$ TGF- $\beta 2$, or $500 \mu \mathrm{mol} / \mathrm{L}$ BSO combined with $1 \mathrm{ng} / \mathrm{mL}$ TGF- $\beta 2$ for 24 hours. Blocking GSH biosynthesis by BSO has a synergistic effect with TGF- $\beta 2$ in $\alpha$-SMA expression (Figure $3 \mathrm{C}$ ).

\section{Wnt/ $\beta$-Catenin Pathway Is Activated by Decreased GSH Levels}

We have excluded TGF- $\beta$ and its canonical signaling pathway in oxidation-mediated EMT. The transcriptome profile and pathway analysis from our separate study ${ }^{44}$ on lens gene adaptation under decreased concentration of GSH by RNA sequencing indicated the $\mathrm{Wnt} / \beta$-catenin signaling was the major pathway associated with EMT signaling. The immunoblot showed that both Wnt10a and $\beta$-catenin protein levels were highly elevated in the extract of whole lens (Figure 4A) and lens epithelium (Figure 4B) of both $\mathrm{Gclc}^{-1-}$ and $\mathrm{Gclm}^{-1-}$ mice compared with WT. XAV939, a 


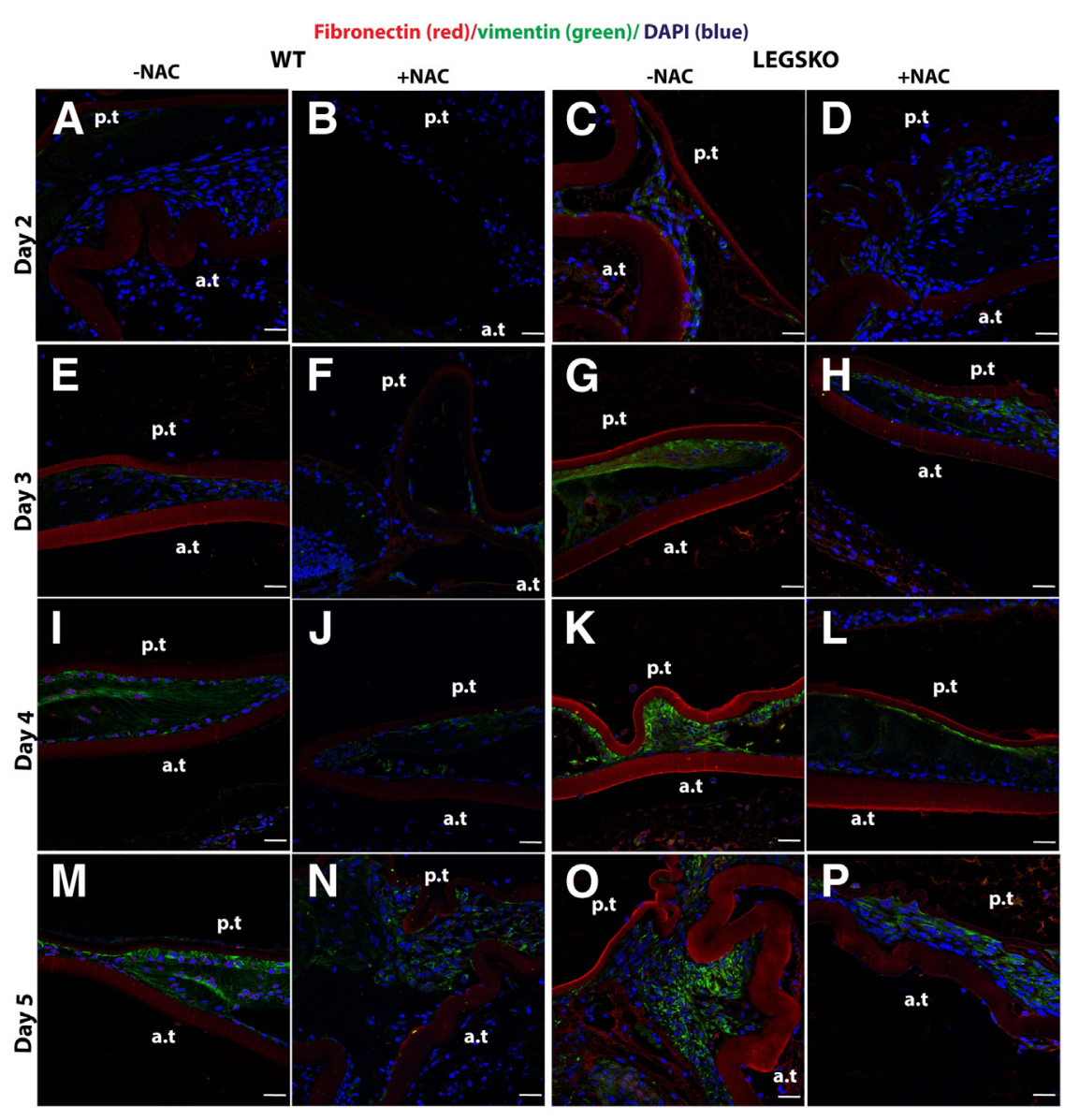

Figure 6 The antioxidant $\mathrm{N}$-acetyl cysteine (NAC) significantly attenuates the EMT signaling in vivo. The fibronectin (red fluorescence) and vimentin (green) were costained in mouse lens capsule 2 to 5 days after mock cataract surgery by removing lens fiber mass. The lens nucleus was stained with DAPI (blue). A, E, I, M and C, G, K, 0: Merged images colocalized for fibronectin (red), vimentin (green), and nucleus (blue) of either WT or LEGSKO mice without $10 \mathrm{mmol} / \mathrm{L}$ NAC treatment. B, F, J, N and D, H, L, P: Merged images colocalized for fibronectin (red), vimentin (green), and nucleus (blue) of either WT or LEGSK0 mice with 10 $\mathrm{mmol} / \mathrm{L}$ NAC treatment. A and B: WT lens capsule at post-surgery day 2 with or without NAC treatment. C and D: LEGSKO lens capsule at postsurgery day 2 with or without NAC treatment. E and F: WT lens capsule at post-surgery day 3 with or without NAC treatment. $\mathbf{G}$ and H: LEGSKO lens capsule at post-surgery day 3 with or without NAC treatment. I and J: WT lens capsule at post-surgery day 4 with or without NAC treatment. $\mathbf{K}$ and $\mathbf{L}$ : LEGSKO lens capsule at post-surgery day 4 with or without NAC treatment. M and N: WT lens capsule at post-surgery day 5 with or without NAC treatment. $\mathbf{0}$ and P: LEGSKO lens capsule at postsurgery day 5 with or without NAC treatment. Six mice at each time point were used. The same confocal parameters in each channel were used to capture the image from all of the samples. Scale bars $=25 \mu \mathrm{m}(\mathbf{A}-\mathbf{P})$. a.t., anterior capsule; p.t., posterior capsule.

Wnt inhibitor, was able to block both $\alpha$-SMA and $\beta$-catenin expression in HLE-B3 cells after being challenged by BSO for 24 hours and the lens epithelium from 48 hours ex vivo lens culture being treated by BSO when co-treated with XAV939 (Figure 4C).

To further dissect the $\mathrm{Wnt} / \beta$-catenin signaling, we targeted the phosphorylation/inactivation of GSK-3 $\beta$, a key event in canonical $\mathrm{Wnt} / \beta$-catenin signaling that affects the assembly of the $\beta$-catenin destruction complex, $\beta$-catenin release, and translocation to the nucleus. The phosphorylation at Ser9, which inactivates GSK-3 $\beta$, was significantly increased in HLE-B3 cells after treatment with BSO for 24 hours and in lens epithelium after whole lens ex vivo culture for 48 hours with BSO (Figure 4D). The increased $\beta$-catenin expression and Ser9 phosphorylation in GSK-3 $\beta$ were both alleviated when cells were cotreated with $0.5 \mathrm{mmol} / \mathrm{L} \mathrm{GSH}-$ $\mathrm{EE}$ or $10 \mathrm{mmol} / \mathrm{L}$ NAC (Figure 4D). To verify whether $\mathrm{Wnt} / \beta$-catenin signaling was activated in lens epithelial cells in vivo, we performed mock cataract surgery on mice by removing the lens fiber mass without damage to the posterior capsule, similar to human cataract surgery but without insertion of an intraocular lens implant. Bilateral eye surgery was performed, whereby the left eye served as control while $25 \mu \mathrm{L}$ of $10 \mathrm{mmol} / \mathrm{L} \mathrm{NAC}$ was injected into the right eye chamber after surgery, followed by continuous topical application of $10 \mathrm{mmol} / \mathrm{L}$ NAC eye drops every 6 hours from $7 \mathrm{AM}$ to $11 \mathrm{PM}$ postoperatively. Robust nuclear colocalization of $\beta$-catenin could be seen in $\mathrm{Gclc}^{-/-}$mice 72 hours after surgery, and this colocalization was significantly attenuated in NAC-treated eyes (Figure 4, E-M).

\section{Impaired GSH Biosynthesis Promotes EMT Signaling in Vivo}

To further clarify the role of oxidative stress in the EMT process in vivo, mock cataract surgery mouse mode was used, as described above. The right eye was used for antioxidant treatment, and the left eye served as control. The tissue collected immediately after surgery was used as a time 0 control. The typical histology at postoperative day 5, visualized by hematoxylin and eosin, is shown in Supplemental Figure S2. The type I collagen and $\alpha$-SMA demonstrated a remarkable increase in LEGSKO mice compared with WT from day 2 to day 5 postoperatively (Figure 5), whereas a barely detectable signal was observed in the time 0 control. Higher signals of these EMT markers were picked up at time 0 in LEGSKO and Gclm KO mice compared with WT when the confocal capture sensitivity was adjusted properly. Massive cell accumulation was seen in the posterior capsule at days 4 and 5 after the surgical 


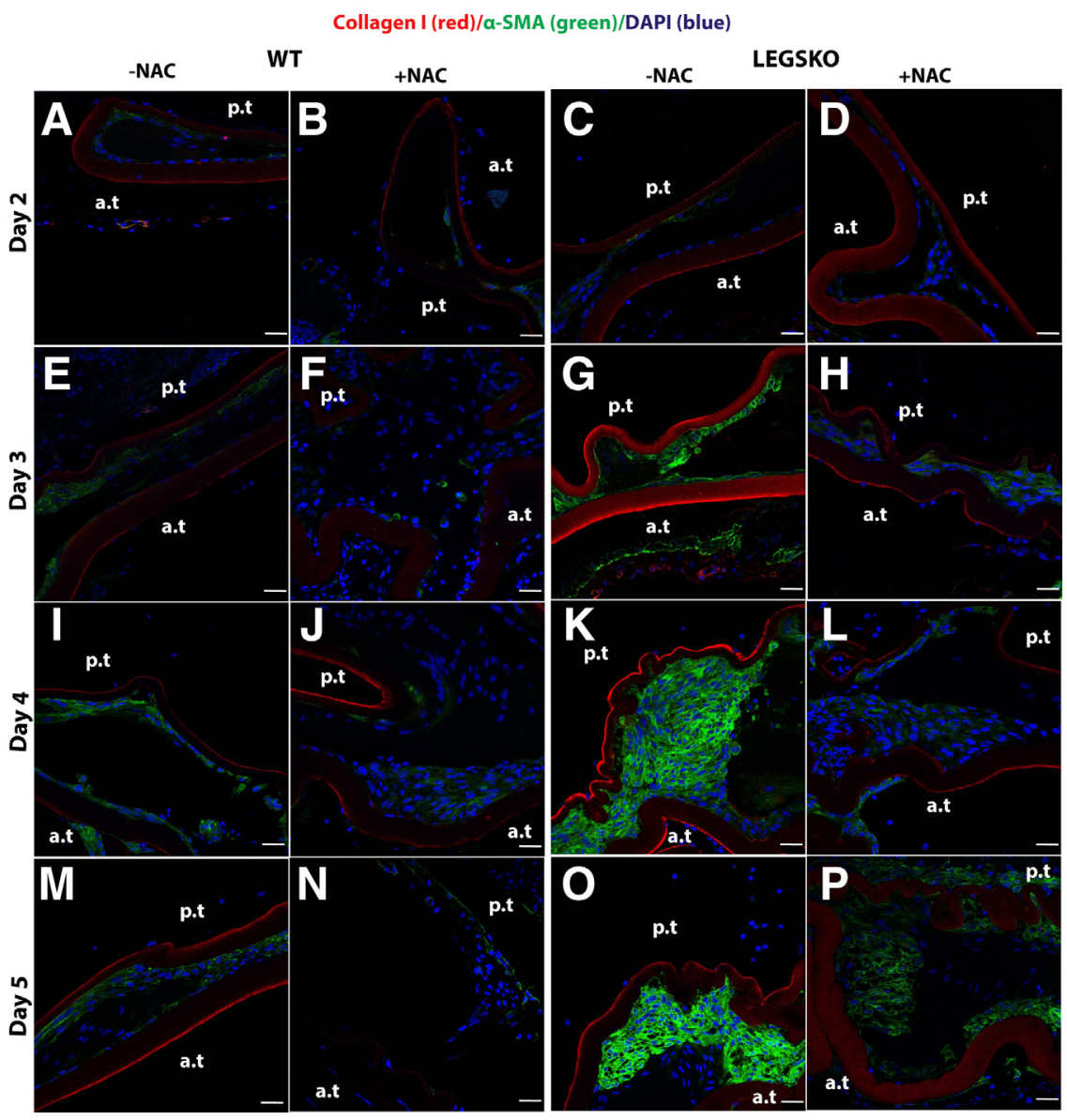

Figure 7 The antioxidant $\mathrm{N}$-acetyl cysteine (NAC) could significantly attenuate the EMT signaling in vivo. The type I collagen (red fluorescence) and $\alpha$-smooth muscle actin ( $\alpha$-SMA; green) were costained in mouse lens capsule 2 to 5 days after mock cataract surgery by removing lens fiber mass. The lens nucleus was stained with DAPI (blue). A, E, I, M and C, G, K, 0: Merged images colocalized for collagen I (red), $\alpha$-SMA (green), and nucleus (blue) of either WT or LEGSKO mice without $10 \mathrm{mmol} / \mathrm{L}$ NAC treatment. B, F, J, N and D, H, L, P: Merged images colocalized for collagen I (red), $\alpha$-SMA (green), and nucleus (blue) of either WT or LEGSKO mice with $10 \mathrm{mmol} / \mathrm{L}$ NAC treatment. A and B: WT lens capsule at post-surgery day 2 with or without NAC treatment. C and D: LEGSKO lens capsule at post-surgery day 2 with or without NAC treatment. $\mathbf{E}$ and $\mathbf{F}$ : WT lens capsule at post-surgery day 3 with or without NAC treatment. $\mathbf{G}$ and $\mathbf{H}$ : LEGSKO lens capsule at post-surgery day 3 with or without NAC treatment. I and J: WT lens capsule at post-surgery day 4 with or without NAC treatment. $\mathbf{K}$ and L: LEGSKO lens capsule at post-surgery day 4 with or without NAC treatment. M and N: WT lens capsule at post-surgery day 5 with or without NAC treatment. $\mathbf{0}$ and P: LEGSKO lens capsule at postsurgery day 5 with or without NAC treatment. Six mice at each time point were used. The same confocal parameters in each channel were used to capture the image from all of the samples. Scale bars $=25 \mu \mathrm{m}(\mathbf{A}-\mathbf{P})$. a.t., anterior capsule; p.t., posterior capsule.

procedure in both WT and LEGSKO mice, but with significant intensity of both collagen I and $\alpha$-SMA in LEGSKO mice compared with WT. Similarly, fibronectin and vimentin also demonstrated significantly increased expression in LEGSKO mice compared with WT (Supplemental Figure S3). The $10 \mathrm{mmol} / \mathrm{L}$ NAC injection immediately after surgery and continuous topical application demonstrated a remarkable attenuation of increased fibronectin/ vimentin (Figure 6) and collagen I/ $\alpha$-SMA (Figure 7) expression compared with control eyes in both WT and LEGSKO mice. As expected, Gclm KO mice also demonstrated profound increases of fibronectin, vimentin, collagen $\mathrm{I}$, and $\alpha$-SMA compared with WT, and $2 \mathrm{mmol} / \mathrm{L}$ GSH-EE could partially, but significantly, attenuated the production of these EMT marker proteins (Figure 8).

\section{Discussion}

The present study elicits, for the first time, the association of oxidation in the pathogenesis of lens fibrosis and posterior capsule opacification formation via a Wnt/ $\beta$-cateninmediated and TGF- $\beta$-independent mechanism. For a long time, TGF- $\beta$ has been considered a key player in lens epithelial fibrosis and PCO formation. However, surprisingly, despite the strong findings from in vitro and ex vivo capsular bag culture showing strong attenuation of EMT and PCO via blocking the TGF- $\beta$-mediated pathway, ${ }^{45,46}$ no effect was found in an in vivo rodent PCO model when an anti-TGF- $\beta 2$ antibody intervention was tested. ${ }^{47}$ Furthermore, PCO is a chronic disease that usually develops a few years after the surgical procedure. Remnant lens epithelial cells have to go through an acute phase immediately after a traumatic injury caused by the surgical procedure, which is followed by a transition to a subacute and chronic phase after the initial wound-healing process is over. Inflammatory cytokines and growth factors, which are produced and reach their peak levels during the acute phase, will continuously decline as the healing stage ends. ${ }^{48-50}$ This is echoed by short- and long-term clinical observations of lens epithelial cell grouping behavior, so-called Elschnig pearls, ${ }^{51,52}$ which indicate that the number and size of Elschnig pearls increase significantly 2 weeks postoperatively but start to decrease or disappear at 4 months postoperatively. The number and size of Elschnig pearls reoccurred at postoperative years 1 to 3 , especially in those patients with PCO complications. These studies suggest that there are unknown processes that continuously drive lens epithelial cell proliferation, migration, and transdifferentiation during the chronic phase. 

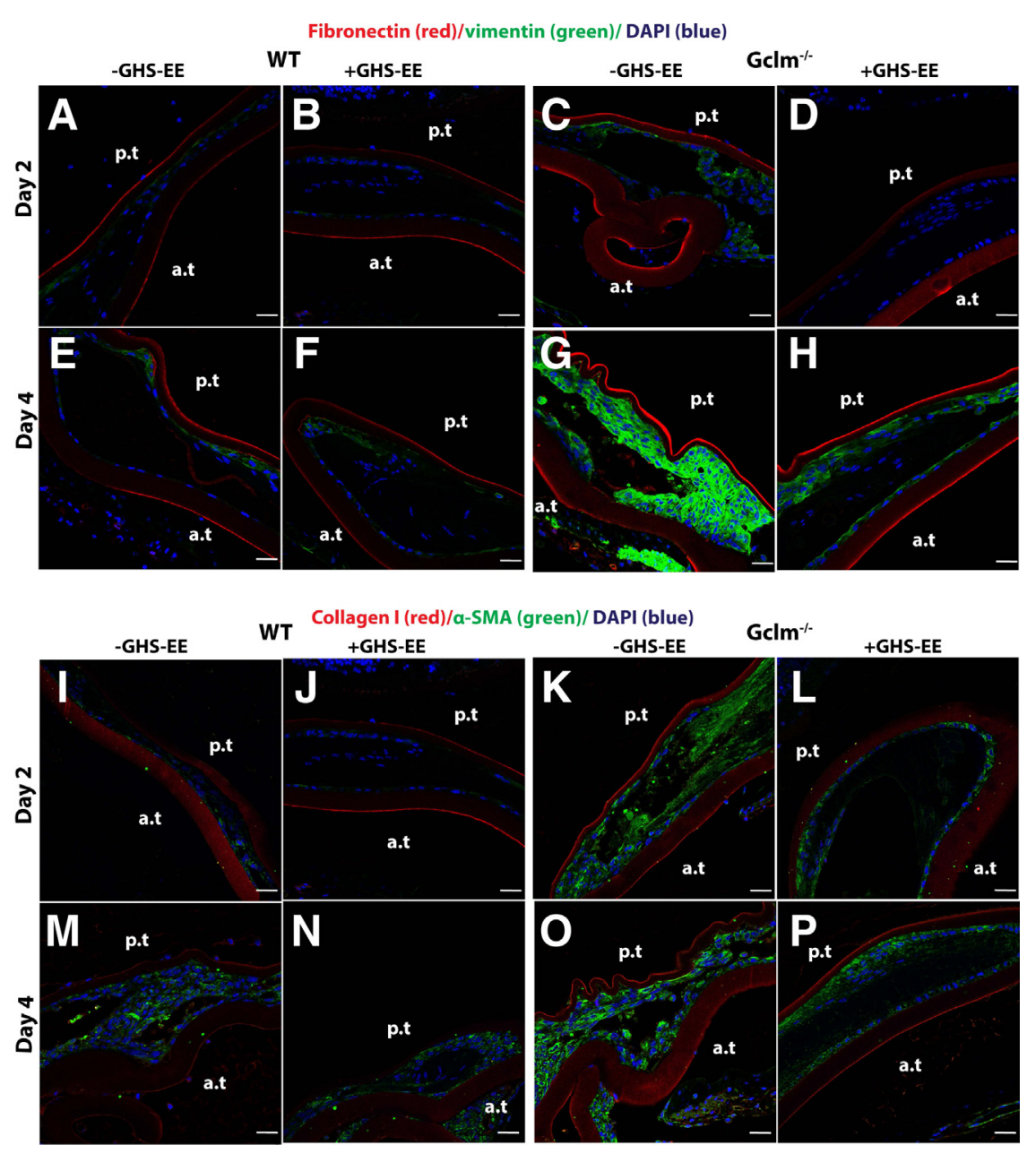

Figure $8 \mathrm{Gclm}$ knockout (KO) mouse modulates EMT signaling in the mock cataract surgery in vivo model. $\mathbf{A}-\mathrm{H}$ : All images are merged for colocalization of fibronectin (red), vimentin (green), and nucleus (blue). A and B: WT lens capsule at post-surgery day 2 with or without 2 $\mathrm{mmol} / \mathrm{L} \mathrm{GSH}$ ethyl ester (GSH-EE) treatment. $\mathrm{C}$ and D: Gclm KO lens capsule at post-surgery day 2 with or without $2 \mathrm{mmol} / \mathrm{L} \mathrm{GSH}-\mathrm{EE}$ treatment. $\mathbf{E}$ and $\mathbf{F}$ : WT lens capsule at post-surgery day 4 with or without $2 \mathrm{mmol} / \mathrm{L}$ GSH-EE treatment. $\mathbf{G}$ and $\mathbf{H}$ : $\mathrm{Gclm}$ KO lens capsule at post-surgery day 4 with or without $2 \mathrm{mmol} / \mathrm{L}$ GSH-EE treatment. I-P: All images are merged for colocalization of collagen I (red), $\alpha$-smooth muscle actin ( $\alpha$-SMA; green), and nucleus (blue). I and J: WT lens capsule at postsurgery day 2 with or without $2 \mathrm{mmol} / \mathrm{L} \mathrm{GSH}-\mathrm{EE}$ treatment. $\mathbf{K}$ and $\mathbf{L}: \mathrm{Gclm}$ KO lens capsule at post-surgery day 2 with or without $2 \mathrm{mmol} / \mathrm{L} \mathrm{GSH}$ EE treatment. $\mathrm{M}$ and $\mathrm{N}$ : WT lens capsule at postsurgery day 4 with or without $2 \mathrm{mmol} / \mathrm{L} \mathrm{GSH}-\mathrm{EE}$ treatment. $\mathbf{0}$ and $\mathbf{P}$ : Gclm $\mathrm{KO}$ lens capsule at post-surgery day 4 with or without $2 \mathrm{mmol} / \mathrm{L} \mathrm{GSH}$ EE treatment. Six mice at each time point were used. The same confocal parameters in each channel were used to capture the images from all of the samples. Scale bars $=25 \mu \mathrm{m}(\mathbf{A}-\mathbf{P})$. a.t., anterior capsule; p.t., posterior capsule.

Our study indicates that declined GSH levels will promote the EMT process in lens epithelial cells associated with elevated expression of fibrotic markers, which is well situated in lens epithelial cells before and after cataract surgery. Lens epithelial cells are surrounded by a capsule at their basolateral side, whereas their apical side is in contact with lens fiber cells. Thus, overall, lens epithelial cells are in a relatively closed growth environment. During cataract surgery, the fiber mass is removed and lens epithelial cells are separated from the lens fiber and are in direct contact with either an intraocular lens or aqueous humor; this is, thus, a relatively open growth environment. Moreover, the lens' outer fiber layer is a GSH-enriched zone with $>10$ $\mathrm{mmol} / \mathrm{L}$ concentration, ${ }^{53}$ whereas the aqueous humor only has approximately $5 \mu \mathrm{mol} / \mathrm{L}$ GSH based on our recent study. ${ }^{40}$ As a result, profound changes occur after cataract surgery, especially in the extracellular GSH content of lens epithelial cells. We hypothesized and suggested in this work that, postoperatively, elevated oxidative stress also becomes part of the lens epithelial cell growth environment and that this profoundly affects the biology of surviving lens epithelial cells. In particular, the biologically inactive intraocular lens is unable to neutralize or detoxify extracellular ROS generated by lens epithelial cells or surrounding ocular fluid.

In addition to a drastic extracellular GSH content change of lens epithelial cells before and after the surgical procedure, oxygen levels also change significantly, as reported by Beebe and colleagues. ${ }^{54,55}$ They showed that partial pressure of oxygen levels surrounding the human lens posterior capsule increase dramatically to $11.0 \mathrm{mmHg}$ compared with no surgery controls (partial pressure of oxygen level, approximately $2.8 \mathrm{mmHg}$ ). The increased oxygen content after surgery might also bring additional oxidative stress to lens epithelial cells. Furthermore, not like TGF- $\beta$ and other cytokines, the reduced GSH levels and increased oxygen content will last the entire time with lens epithelial cells after the surgical procedure. We speculate that this chronic oxidative stress condition is playing a pivotal role in PCO formation. However, our current study only addresses the impact of declined GSH levels on lens epithelial cell fibrosis. The role of elevated oxygen content in lens epithelial cell fibrosis and PCO formation after surgery still needs to be further clarified.

ROS have been implicated as playing a pivotal role in EMT signaling and tissue fibrosis either acting alone or by modulating TGF- $\beta$-mediated signaling..$^{25,26,29,30}$ On the 
one hand, TGF- $\beta$ can increase intracellular ROS formation by either increasing the NADPH oxidase production or impairing the intracellular antioxidant defense system (ie, inhibiting GSH biosynthesis). ${ }^{56,57}$ On the other hand, ROS could often either induce TGF- $\beta$ production or activate TGF- $\beta$ from its latent state. ${ }^{28,58}$ In the present study, we found that blocking intracellular GSH biosynthesis could trigger EMT signaling based on two GSH biosynthesis deficiency mouse models and lens epithelial cells after either BSO or DMF stimulation to reduce intracellular GSH levels (Figures 1 and 2). Equally important, coincubation with an antioxidant (ie, GSH-EE or NAC) could attenuate EMT signaling in a significant manner (Figure 2). Surprisingly, we found no remarkable changes in total and active TGF- $\beta 2$ (the major isoform in the lens ${ }^{59}$ ) levels in the aqueous humor or in the phosphorylation status of Smad2/3, a key event in canonical TGF- $\beta$ signaling, in LEGSKO and $\mathrm{Gclm}^{-1-}$ lenses compared with WT (Figure 3 and Table 1). Furthermore, the decreased intracellular GSH concentration was found to have a synergistic effect in EMT signaling with TGF- $\beta 2$ (Figure 3). These results suggest that EMT signaling induced by decreased intracellular GSH levels is independent of TGF- $\beta$ pathway.

Further study suggests that the EMT signaling modulated by decreased intracellular GSH concentrations is mediated via a $\mathrm{Wnt} / \beta$-catenin signaling pathway. A $>20$-fold upregulation of Wnt10a was found in our recent RNAsequencing study when comparing lens epithelial cells' gene transcriptome profile between LEGSKO and WT mice. ${ }^{44}$ We saw an over twofold Wnt10a protein expression in the lens capsule. The discrepancy between mRNA and protein up-regulation might be because of Wnt10a secretion into the extracellular space (ie, aqueous humor) because Wnt protein secretion is a common mechanism for its signal transduction. ${ }^{60}$ Activation of the Wnt and Frizzled receptor complex subsequently disrupts the adenomatous plolyposis coli/Axin/GSK-3 $\beta$ complex, triggering phosphorylation and inactivation of GSK-3 $\beta$ (ie, Ser9 phosphorylation), which, in turn, stabilizes $\beta$-catenin, allowing $\beta$-catenin nuclear translocation and target gene regulation. ${ }^{61,62} \mathrm{We}$ found GSK- $3 \beta^{\text {Ser9 }}$ was significantly increased in the mouse lens epithelium when GSH biosynthesis is impaired and when human lens epithelial cells are being challenged by BSO (Figure 4). Furthermore, the fact that the phosphorylation of Ser9 could be completely abolished when cotreating the cells with $10 \mathrm{mmol} / \mathrm{L} \mathrm{NAC}$ suggests that the $\mathrm{Wnt} / \beta$-catenin-mediated EMT signaling is oxidative stress dependent. Oxidative stress, with production of ROS and reactive nitrogen species, is not only limited to toxic effect but also functions as an intracellular messenger, regulating gene expression and cell adaptation in both physiological and pathological conditions. The pioneering work from Funato et $\mathrm{al}^{63}$ suggests that ROS can modulate signaling by the Wnt/ $\beta$-catenin pathway. Later on, Parola and colleagues ${ }^{64}$ demonstrated that hypoxia-induced mitochondrial ROS production could activate the $\mathrm{Wnt} / \beta$-catenin signaling pathway via phosphorylation/inactivation of GSK-3 $\beta$, which is in perfect agreement with our current study.

More important, the mouse cataract surgery model we tested in this study demonstrates a pivotal role that oxidative stress plays in lens epithelial cell transformation and PCO formation. The remarkable elevated expression levels of various EMT markers, such as type I collagen, vimentin, fibronectin, and $\alpha$-SMA, in both LEGSKO and $\mathrm{Gclm}^{-1-}$ mice strongly suggest that oxidation could modulate intracellular gene expression and cell adaptation (Figures 5-8). In this case, oxidative stress produced by decreased intracellular GSH concentration promotes cell transformation rather than apoptosis. Intriguingly, both NAC and GSH-EE could significantly attenuate EMT signaling. NAC had a much higher inhibitory effect than GSH-EE in both cell culture and in vivo cataract surgery models, suggesting that the sulfhydryl group of these compounds alone is sufficient to attenuate the oxidation-reduction status that regulates Wnt $/ \beta$-catenin-mediated EMT signaling (Figures $6-8$ ). In addition, postoperative $\beta$-catenin nuclear translocation in both WT and GSH biosynthesis deficiency mouse models of this study further supports our hypothesis that oxidative stress could promote EMT via the Wnt/ $\beta$-catenin pathway. Currently, one limitation is that the above conclusions are based on our mouse cataract surgery model and will have to be verified with lens epithelial cells in contact with an actual intraocular lens implant. Such experiments are currently in progress in our laboratory.

In summary, the present study demonstrates that moderate oxidative stress can modulate lens epithelial cell transformation via the $\mathrm{Wnt} / \beta$-catenin-mediated and TGF- $\beta$-independent EMT signaling pathway in vitro and in vivo. This study suggests that antioxidant intervention is a potential therapeutic approach to treat PCO formation.

\section{Acknowledgments}

We thank Dr. Vincent M. Monnier for helpful discussions and proofreading of the manuscript; members of the Fan and Monnier laboratories for helpful discussions; Dr. Melinda K. Duncan (University of Delaware) for suggestions in mouse cataract surgery experiments; and Catherine Doller and Dr. Scott Howell (Case Western Reserve University Vision Science Research Center) for tissue sectioning and microscope image collections.

Z.W. and X.F. conceived the research; Z.W., J.C., A.D.Z., J.W., R.S., H.Y., and X.F. acquired the data; T.J.K. contributed critical reagents; X.F. supervised the research; Z.W., H.Y., and X.F. analyzed and interpreted the data; Z.W. and X.F. wrote the manuscript.

\section{Supplemental Data}

Supplemental material for this article can be found at http://dx.doi.org/10.1016/j.ajpath.2017.07.018. 


\section{References}

1. Liu YC, Wilkins M, Kim T, Malyugin B, Mehta JS: Cataracts. Lancet 2017, 390:600-612

2. Eldred JA, Dawes LJ, Wormstone IM: The lens as a model for fibrotic disease. Philos Trans R Soc Lond B Biol Sci 2011, 366:1301-1319

3. Dawes LJ, Sleeman MA, Anderson IK, Reddan JR, Wormstone IM: TGFbeta/Smad4-dependent and -independent regulation of human lens epithelial cells. Invest Ophthalmol Vis Sci 2009, 50:5318-5327

4. Walker JL, Wolff IM, Zhang L, Menko AS: Activation of SRC kinases signals induction of posterior capsule opacification. Invest Ophthalmol Vis Sci 2007, 48:2214-2223

5. Mamuya FA, Wang Y, Roop VH, Scheiblin DA, Zajac JC, Duncan MK: The roles of alphaV integrins in lens EMT and posterior capsular opacification. J Cell Mol Med 2014, 18:656-670

6. He J, Xu Y, Koya D, Kanasaki K: Role of the endothelial-tomesenchymal transition in renal fibrosis of chronic kidney disease. Clin Exp Nephrol 2013, 17:488-497

7. Carew RM, Wang B, Kantharidis P: The role of EMT in renal fibrosis. Cell Tissue Res 2012, 347:103-116

8. Lee SJ, Kim KH, Park KK: Mechanisms of fibrogenesis in liver cirrhosis: the molecular aspects of epithelial-mesenchymal transition. World J Hepatol 2014, 6:207-216

9. Nowrin K, Sohal SS, Peterson G, Patel R, Walters EH: Epithelialmesenchymal transition as a fundamental underlying pathogenic process in COPD airways: fibrosis, remodeling and cancer. Expert Rev Respir Med 2014, 8:547-559

10. Marcantonio JM, Syam PP, Liu CS, Duncan G: Epithelial transdifferentiation and cataract in the human lens. Exp Eye Res 2003, 77: 339-346

11. Wormstone IM: Posterior capsule opacification: a cell biological perspective. Exp Eye Res 2002, 74:337-347

12. Lamouille S, Xu J, Derynck R: Molecular mechanisms of epithelialmesenchymal transition. Nat Rev Mol Cell Biol 2014, 15:178-196

13. Saika S, Okada Y, Miyamoto T, Ohnishi Y, Ooshima A, McAvoy JW: Smad translocation and growth suppression in lens epithelial cells by endogenous TGFbeta2 during wound repair. Exp Eye Res 2001, 72:679-686

14. Saika S, Miyamoto T, Ishida I, Shirai K, Ohnishi Y, Ooshima A, McAvoy JW: TGFbeta-Smad signalling in postoperative human lens epithelial cells. Br J Ophthalmol 2002, 86:1428-1433

15. Tiwari A, Ram J, Luthra-Guptasarma M: Targeting the fibronectin type III repeats in tenascin-C inhibits epithelial-mesenchymal transition in the context of posterior capsular opacification. Invest Ophthalmol Vis Sci 2014, 56:272-283

16. Ishibashi $\mathrm{T}$, Hatae $\mathrm{T}$, Inomata H: Collagen types in human posterior capsule opacification. J Cataract Refract Surg 1994, 20:643-646

17. Linnola RJ, Werner L, Pandey SK, Escobar-Gomez M, Znoiko SL, Apple DJ: Adhesion of fibronectin, vitronectin, laminin, and collagen type IV to intraocular lens materials in pseudophakic human autopsy eyes, part 2: explanted intraocular lenses. J Cataract Refract Surg 2000, 26:1807-1818

18. Linnola RJ, Werner L, Pandey SK, Escobar-Gomez M, Znoiko SL, Apple DJ: Adhesion of fibronectin, vitronectin, laminin, and collagen type IV to intraocular lens materials in pseudophakic human autopsy eyes, part 1: histological sections. J Cataract Refract Surg 2000, 26 : $1792-1806$

19. Raghavan CT, Smuda M, Smith AJ, Howell S, Smith DG, Singh A, Gupta P, Glomb MA, Wormstone IM, Nagaraj RH: AGEs in human lens capsule promote the TGFbeta2-mediated EMT of lens epithelial cells: implications for age-associated fibrosis. Aging Cell 2016, 15 : 465-476

20. Wormstone IM, Tamiya S, Anderson I, Duncan G: TGF-beta2induced matrix modification and cell transdifferentiation in the human lens capsular bag. Invest Ophthalmol Vis Sci 2002, 43: $2301-2308$
21. Dawes LJ, Elliott RM, Reddan JR, Wormstone YM, Wormstone IM: Oligonucleotide microarray analysis of human lens epithelial cells: TGFbeta regulated gene expression. Mol Vis 2007, 13:1181-1197

22. Morry J, Ngamcherdtrakul W, Yantasee W: Oxidative stress in cancer and fibrosis: opportunity for therapeutic intervention with antioxidant compounds, enzymes, and nanoparticles. Redox Biol 2017, 11: 240-253

23. Cannito S, Novo E, di Bonzo LV, Busletta C, Colombatto S, Parola M: Epithelial-mesenchymal transition: from molecular mechanisms, redox regulation to implications in human health and disease. Antioxid Redox Signal 2010, 12:1383-1430

24. Mori K, Shibanuma M, Nose K: Invasive potential induced under long-term oxidative stress in mammary epithelial cells. Cancer Res 2004, 64:7464-7472

25. Mahalingaiah PK, Ponnusamy L, Singh KP: Chronic oxidative stress leads to malignant transformation along with acquisition of stem cell characteristics, and epithelial to mesenchymal transition in human renal epithelial cells. J Cell Physiol 2015, 230:1916-1928

26. Droge W: Free radicals in the physiological control of cell function. Physiol Rev 2002, 82:47-95

27. Novo E, Parola M: Redox mechanisms in hepatic chronic wound healing and fibrogenesis. Fibrogenesis Tissue Repair 2008, 1:5

28. Bellocq A, Azoulay E, Marullo S, Flahault A, Fouqueray B, Philippe C, Cadranel J, Baud L: Reactive oxygen and nitrogen intermediates increase transforming growth factor-betal release from human epithelial alveolar cells through two different mechanisms. Am J Respir Cell Mol Biol 1999, 21:128-136

29. Jaffer OA, Carter AB, Sanders PN, Dibbern ME, Winters CJ, Murthy S, Ryan AJ, Rokita AG, Prasad AM, Zabner J, Kline JN, Grumbach IM, Anderson ME: Mitochondrial-targeted antioxidant therapy decreases transforming growth factor-beta-mediated collagen production in a murine asthma model. Am J Respir Cell Mol Biol 2015, 52:106-115

30. Jarman ER, Khambata VS, Cope C, Jones P, Roger J, Ye LY, Duggan N, Head D, Pearce A, Press NJ, Bellenie B, Sohal B, Jarai G: An inhibitor of NADPH oxidase-4 attenuates established pulmonary fibrosis in a rodent disease model. Am J Respir Cell Mol Biol 2014, 50:158-169

31. Aoyama T, Paik YH, Watanabe S, Laleu B, Gaggini F, FiorasoCartier L, Molango S, Heitz F, Merlot C, Szyndralewiez C, Page P, Brenner DA: Nicotinamide adenine dinucleotide phosphate oxidase in experimental liver fibrosis: GKT137831 as a novel potential therapeutic agent. Hepatology 2012, 56:2316-2327

32. Amara N, Goven D, Prost F, Muloway R, Crestani B, Boczkowski J: NOX4/NADPH oxidase expression is increased in pulmonary fibroblasts from patients with idiopathic pulmonary fibrosis and mediates TGFbeta1-induced fibroblast differentiation into myofibroblasts. Thorax 2010, 65:733-738

33. Deger Y, Yur F, Ertekin A, Mert N, Dede S, Mert H: Protective effect of alpha-tocopherol on oxidative stress in experimental pulmonary fibrosis in rats. Cell Biochem Funct 2007, 25:633-637

34. Iyer SS, Ramirez AM, Ritzenthaler JD, Torres-Gonzalez E, RoserPage S, Mora AL, Brigham KL, Jones DP, Roman J, Rojas M: Oxidation of extracellular cysteine/cystine redox state in bleomycininduced lung fibrosis. Am J Physiol Lung Cell Mol Physiol 2009, 296:L37-L45

35. Roum JH, Buhl R, McElvaney NG, Borok Z, Crystal RG: Systemic deficiency of glutathione in cystic fibrosis. J Appl Physiol (1985) 1993, 75:2419-2424

36. Rahman I, Skwarska E, Henry M, Davis M, O'Connor CM, FitzGerald MX, Greening A, MacNee W: Systemic and pulmonary oxidative stress in idiopathic pulmonary fibrosis. Free Radic Biol Med 1999, 27:60-68

37. Bianchi G, Bugianesi E, Ronchi M, Fabbri A, Zoli M, Marchesini G: Glutathione kinetics in normal man and in patients with liver cirrhosis. J Hepatol 1997, 26:606-613 
38. Fan X, Liu X, Hao S, Wang B, Robinson ML, Monnier VM: The LEGSKO mouse: a mouse model of age-related nuclear cataract based on genetic suppression of lens glutathione synthesis. PLoS One 2012, 7:e50832

39. Cole TB, Giordano G, Co AL, Mohar I, Kavanagh TJ, Costa LG: Behavioral characterization of GCLM-knockout mice, a model for enhanced susceptibility to oxidative stress. J Toxicol 2011, 2011: 157687

40. Whitson JA, Sell DR, Goodman MC, Monnier VM, Fan X: Evidence of dual mechanisms of glutathione uptake in the rodent lens: a novel role for vitreous humor in lens glutathione homeostasis. Invest Ophthalmol Vis Sci 2016, 57:3914-3925

41. Fan X, Sell DR, Zhang J, Nemet I, Theves M, Lu J, Strauch C, Halushka MK, Monnier VM: Anaerobic vs aerobic pathways of carbonyl and oxidant stress in human lens and skin during aging and in diabetes: a comparative analysis. Free Radic Biol Med 2010, 49: $847-856$

42. Zhu XJ, Chen MJ, Zhang KK, Yang J, Lu Y: Elevated TGF-beta2 level in aqueous humor of cataract patients with high myopia: potential risk factor for capsule contraction syndrome. J Cataract Refract Surg 2016, 42:232-238

43. Matthaei M, Gillessen J, Muether PS, Hoerster R, Bachmann BO, Hueber A, Cursiefen C, Heindl LM: Epithelial-mesenchymal transition (EMT)-related cytokines in the aqueous humor of phakic and pseudophakic Fuchs' dystrophy eyes. Invest Ophthalmol Vis Sci 2015, 56:2749-2754

44. Whitson JA, Zhang X, Medvedovic M, Chen J, Wei Z, Monnier VM, Fan X: Transcriptome of the GSH-depleted lens reveals changes in detoxification and EMT signaling genes, transport systems, and lipid homeostasis. Invest Ophthalmol Vis Sci 2017, 58:2666-2684

45. Eldred JA, Hodgkinson LM, Dawes LJ, Reddan JR, Edwards DR, Wormstone IM: MMP2 activity is critical for TGFbeta2-induced matrix contraction: implications for fibrosis. Invest Ophthalmol Vis Sci 2012, 53:4085-4098

46. Wormstone IM, Anderson IK, Eldred JA, Dawes LJ, Duncan G: Short-term exposure to transforming growth factor beta induces longterm fibrotic responses. Exp Eye Res 2006, 83:1238-1245

47. Lois N, Taylor J, McKinnon AD, Smith GC, van't Hof R, Forrester JV: Effect of TGF-beta2 and anti-TGF-beta2 antibody in a new in vivo rodent model of posterior capsule opacification. Invest Ophthalmol Vis Sci 2005, 46:4260-4266

48. Namiki M: [Quantification of basic fibroblast growth factor (bFGF) and transforming growth factor (TGF alpha) in rabbit aqueous humor after intraocular lens implantation] Japanese. Nippon Ganka Gakkai Zasshi 1994, 98:334-339

49. Zhaohui Z, Shouzhi H: An experimental study of the tumour necrosis factor levels in aqueous humor after traumatic cataract and intraocular lens implantation. Chin Med Sci J 1999, 14:64-66

50. Kawai $\mathrm{M}$, Inoue $\mathrm{T}$, Inatani $\mathrm{M}$, Tsuboi $\mathrm{N}$, Shobayashi $\mathrm{K}$, Matsukawa A, Yoshida A, Tanihara H: Elevated levels of monocyte chemoattractant protein-1 in the aqueous humor after phacoemulsification. Invest Ophthalmol Vis Sci 2012, 53:7951-7960

51. Buehl W, Findl O, Neumayer T, Georgopoulos M, Sacu S: Shortterm changes in the morphology of posterior capsule opacification. J Cataract Refract Surg 2005, 31:962-968

52. Neumayer T, Findl O, Buehl W, Sacu S, Menapace R, Georgopoulos M: Long-term changes in the morphology of posterior capsule opacification. J Cataract Refract Surg 2005, 31: 2120-2128

53. Giblin FJ: Glutathione: a vital lens antioxidant. J Ocul Pharmacol Ther 2000, 16:121-135

54. Beebe DC, Shui YB, Siegfried CJ, Holekamp NM, Bai F: Preserve the (intraocular) environment: the importance of maintaining normal oxygen gradients in the eye. Jpn J Ophthalmol 2014, 58: 225-231

55. Siegfried CJ, Shui YB, Holekamp NM, Bai F, Beebe DC: Oxygen distribution in the human eye: relevance to the etiology of open-angle glaucoma after vitrectomy. Invest Ophthalmol Vis Sci 2010, 51: $5731-5738$

56. Liu RM, Vayalil PK, Ballinger C, Dickinson DA, Huang WT, Wang S, Kavanagh TJ, Matthews QL, Postlethwait EM: Transforming growth factor beta suppresses glutamate-cysteine ligase gene expression and induces oxidative stress in a lung fibrosis model. Free Radic Biol Med 2012, 53:554-563

57. Cui Y, Robertson J, Maharaj S, Waldhauser L, Niu J, Wang J, Farkas L, Kolb M, Gauldie J: Oxidative stress contributes to the induction and persistence of TGF-beta1 induced pulmonary fibrosis. Int J Biochem Cell Biol 2011, 43:1122-1133

58. Barcellos-Hoff MH, Dix TA: Redox-mediated activation of latent transforming growth factor-beta 1. Mol Endocrinol 1996, 10: $1077-1083$

59. Saika S, Miyamoto T, Kawashima Y, Okada Y, Yamanaka O, Ohnishi Y, Ooshima A: Immunolocalization of TGF-beta1, -beta2, and -beta3, and TGF-beta receptors in human lens capsules with lens implants. Graefes Arch Clin Exp Ophthalmol 2000, 238:283-293

60. Mikels AJ, Nusse R: Wnts as ligands: processing, secretion and reception. Oncogene 2006, 25:7461-7468

61. Wu D, Pan W: GSK3: a multifaceted kinase in Wnt signaling. Trends Biochem Sci 2010, 35:161-168

62. Karrasch T, Spaeth T, Allard B, Jobin C: PI3K-dependent GSK3ss(Ser9)-phosphorylation is implicated in the intestinal epithelial cell wound-healing response. PLoS One 2011, 6:e26340

63. Funato Y, Michiue T, Asashima M, Miki H: The thioredoxin-related redox-regulating protein nucleoredoxin inhibits Wnt-beta-catenin signalling through dishevelled. Nat Cell Biol 2006, 8:501-508

64. Cannito S, Novo E, Compagnone A, Valfre di Bonzo L, Busletta C, Zamara E, Paternostro C, Povero D, Bandino A, Bozzo F, Cravanzola C, Bravoco V, Colombatto S, Parola M: Redox mechanisms switch on hypoxia-dependent epithelial-mesenchymal transition in cancer cells. Carcinogenesis 2008, 29:2267-2278 